$$
\begin{array}{ccccccc}
\text { L } & \text { E } & \text { T } & \text { u } & \text { v } & \text { о } & \text { s } \\
\hline \text { ARCHEOlogija } & 47
\end{array}
$$



Lietuvos istorijos institutas

\begin{tabular}{llllllll}
$\mathrm{L}$ & $\mathrm{I}$ & $\mathrm{E}$ & $\mathrm{T}$ & $\mathrm{U}$ & $\mathrm{V}$ & $\mathrm{O}$ & $\mathrm{S}$ \\
\hline
\end{tabular}

ARCHEOlogija 47 


\section{Leidybą finansavo}

\section{LIETUVOS MOKSLO TARYBA}

PAGAL VALSTYBINĘ LITUANISTINIŲ TYRIMŲ IR SKLAIDOS 2016-2024 METŲ PROGRAMĄ

(Finansavimo sutarties numeris S-LIP-19-4)

\section{Redaktorių kolegija / Editorial board:}

Atsakingoji redaktorė / Editor-in-chief dr. Agnè Čivilytė (Lietuvos istorijos institutas, Vilnius / Lithuanian Institute of History, Vilnius)

Atsakingosios redaktorès pavaduotoja / Assistant Editor dr. Elena Pranckènaitè (Lietuvos istorijos institutas, Vilnius / Lithuanian Institute of History, Vilnius)

Dr. Laurynas Kurila (Lietuvos istorijos institutas, Vilnius / Lithuanian Institute of History, Vilnius)

Dr. Valdis Bērziņš (Latvijos universitetas, Latvijos istorijos institutas, Ryga / University of Latvia, Institute of Latvian History, Riga)

Habil. dr. Anna Bitner-Wróblewska (Valstybinis archeologijos muziejus Varšuvoje, Lenkija / State Archaeological Museum in Warsaw, Poland)

Dr. Christoph Jahn (Baltijos ir Skandinavijos archeologijos centras, Šlèzvigas, Vokietija / Center for Baltic and Scandinavian Archaeology, Schleswig, Germany)

Prof. dr. Rimantas Jankauskas (Vilniaus universitetas, Lietuva / Vilnius University, Lithuania)

Akad. prof. dr. Eugenijus Jovaiša (Lietuvos mokslu akademija, Vilnius / Lithuanian Academy of Sciences, Vilnius)

Habil. dr. Bartosz Kontny (Varšuvos universitetas, Archeologijos fakultetas, Lenkija / Faculty of Archaeology, University of Warsaw, Poland)

Prof. dr. Valter Lang (Tartu universitetas, Estija / University of Tartu, Estonia)

Doc. dr. Algimantas Merkevičius (Vilniaus universitetas, Lietuva / Vilnius University, Lithuania)

Habil. dr. Tomasz Nowakiewicz (Varšuvos universitetas, Archeologijos fakultetas, Lenkija / Faculty of Archaeology, University of Warsaw, Poland)
Habil. dr. Grzegorz Osipowicz (Mikalojaus Koperniko universitetas, Torunè, Lenkija / Nicolaus Copernicus University, Toruń, Poland)

Dr. Gytis Piličiauskas (Lietuvos istorijos institutas, Vilnius / Lithuanian Institute of History, Vilnius)

Dr. Eve Rannamäe (Tartu universtitetas, Estija / University of Tartu, Estonia)

Dr. Andra Simniškyte (Lietuvos istorijos institutas, Vilnius / Lithuanian Institute of History, Vilnius)

Dr. Roberts Spirgis (Latvijos universitetas, Latvijos istorijos institutas, Ryga / University of Latvia, Institute of Latvian History, Riga)

Dr. Eugenijus Svetikas (Lietuvos istorijos institutas, Vilnius / Lithuanian Institute of History, Vilnius)

Dr. Andris Šnē (Latvijos universitetas, Ryga / University of Latvia, Riga)

Doc. dr. Gintautas Zabiela (Klaipédos universitetas, Lietuva / Klaipéda University, Lithuania)

Prof. dr. Šarūnas Milišauskas (Niujorko valstijos Bafalo universitetas, JAV / New York State University at Buffalo, USA)

Prof. dr. Timothy Chevral (Niujorko valstijos Bafalo universitetas, JAV / New York State University at Buffalo, USA)

Prof. dr. Johan Ling (Gioteborgo universitetas, Švedija / University of Gothenburg, Sweden)

Sekretorè / Secretary Dovilè Urbonavičiūtė-Jankauskienė

Redakcijos adresas / Editorial Board address:

Lietuvos istorijos institutas, Archeologijos skyrius

Tilto g. 17, LT-01101 Vilnius

Tel. (+370) 5 2614436, fax (+370) 52611433

e-mail: lietuvosarcheologija@gmail.com; civilytea@gmail.com

\section{Žurnalas registruotas: EBSCO Publishing: Central and Eastern European Academic Source European Reference Index for the Humanities and Social Sciences (ERIH PLUS)}




\section{TURINYS / CONTENT}

Agnè Čivilytė

Ernestine S. Elster

James Patrick Mallory
PRATARME் 7

FOREWORD 11

\section{MARIJA GIMBUTIENE் KAIP ASMENYBE் / MARIJA GIMBUTAS AS PERSONALITY}

MARIJA GIMBUTAS, HER EXCAVATIONS, AND THE CONCEPT OF OLD EUROPE / MARIJA GIMBUTIENĖ, ARCHEOLOGINIAI KASINĖJIMAI IR SENOJI EUROPA .15

MARIJA GIMBUTAS IN THE CLASSROOM, FIELD AND OFFICE: A SHORT PERSONAL REMINISCENCE / MARIJA GIMBUTIENE KLASĖJE, KASINĖJIMUOSE IR KABINETE: TRUMPI ASMENINIAI PRISIMINIMAI .31

Kornelija Jankauskaitė MARIJA GIMBUTIENÉ: KELIAUTOJA IR TYRĖJA / MARIJA GIMBUTAS: TRAVELLER AND RESEARCHER .43

\section{STRAIPSNIAI / ARTICLES}

Šarūnas Milišauskas MARIJA GIMBUTAS (GIMBUTIENĖ): THE BALTIC GODDESS .55 MARIJA GIMBUTIENĖ: BALTŲ DEIVE். .88

Julia Mattes

ANTHROPOMORPHIC FIGURINES, GYNOCENTRISM AND GIMBUTAS' RECEPTION INSIDE ARCHAEOLOGY AND BEYOND .91

ANTROPOMORFINĖS FIGŪRĖLĖS, GINOCENTRIZMAS IR MARIJOS GIMBUTIENĖS IDĖJOS ARCHEOLOGIJOJE BEI UŽ JOS RIBŲ 123

MELLAART, GIMBUTAS, GODDESSES, AND ÇATALHÖYÜK: EARLY ASSUMPTIONS AND RECENT PERSPECTIVES ON THE ÇATALHÖYÜK FINDS 125

MELLAARTAS, GIMBUTIENĖ, DEIVĖS IR ČATAL HIUJUKAS: PIRMOSIOS PRIELAIDOS IR NAUJAUSIA RADINIŲ IŠ ČATAL HIUJUKO APŽVALGA 143 
Sharada Srinivasan

Rasa Banytè-Rowell

Florin Gogâltan

Gytis Piličiauskas Edvardas Simčenka Justina Kozakaitè Žydrūnè Miliauskienė Giedrè Piličiauskienè Harry Kenneth Robson

Janusz Czebreszuk Agnè Čivilytė

Paulius Gritènas

Artūras Dubonis
GODDESS WORSHIP AND THE DANCING FORM: EXPLORING RITUAL IN INDIAN PREHISTORY AND SOUTH INDIAN ANTIQUITY 145 DEIVĖS GARBINIMAS IR ŠOKIO JUDESIO FORMA: RITUALAI INDIJOS PRIEŠISTORĖJE IR PIETŲ INDIJOS ANTIKOJE 164

MARIJA GIMBUTAS’ DISSERTATION AND ITS VALUE:

BURIAL CUSTOMS IN THE ROMAN IRON AGE. 167 MARIJOS GIMBUTIENĖS DISERTACIJA IR JOS SVARBA: ROMĖNIŠKOJO LAIKOTARPO LAIDOSENA 185

TRANSYLVANIA AND THE OF INDO-EUROPEAN MIGRATION PROBLEM. THE ROMANIAN PARADIGM 187 TRANSILVANIJA IR INDOEUROPIEČIŲ MIGRACIJOS PROBLEMA. RUMUNIJOS PARADIGMA 207

DONKALNIO IR SPIGINO KAPINYNŲ AKMENS AMŽIAUS ŽMONIŲ KILMÉ IR MOBILUMAS STRONCIO IZOTOPŲ ANALIZĖS DUOMENIMIS. 209

THE ORIGINS AND MOBILITY PATTERNS OF STONE AGE HUMANS FROM THE DONKALNIS AND SPIGINAS BURIAL GROUNDS ACCORDING TO STRONTIUM ISOTOPE ANALYSIS. . .232

PROFESSOR MARIJA GIMBUTAS' ADVENTURE WITH PREHISTORIC AMBER AND THE RESULTS FOR US. 235 MARIJOS GIMBUTIENÉS PRIEŠISTORINIO GINTARO TYRINĖJIMAI IR JŲ REIKŠMĖ ŠIANDIEN 247

\section{KITAIP APIE ARCHEOLOGIJĄ /} ALTERNATIVE PERCEPTIONS OF ARCHAEOLOGY

FILOSOFIJA KAIP ARCHEOLOGIJA 249

\section{RECENZIJOS / REVIEWS}

RYTIS JONAITIS, IRMA KAPLŪNAITE்.

SENKAPIS VILNIUJE, BOKŠTO GATVËJE. XIII-XV A.

LAIDOSENOS LIETUVOJE BRUOŽAI. .253

AUTORIŲ DE்MESIUI 259

GUIDELINES FOR AUTHORS 263 


\title{
GODDESS WORSHIP AND THE DANCING FORM: EXPLORING RITUAL IN INDIAN PREHISTORY AND SOUTH INDIAN ANTIQUITY
}

\author{
SHARADA SRINIVASAN
}

National Institute of Advanced Studies, Indian Institute of Science Campus, Bengaluru 560012, e-mail:

Sharadasrini@nias.res.in

\begin{abstract}
The Indian subcontinent has been one of the regions of the world where the worship of goddesses has been amongst the most longstanding. The seminal work of Marija Gimbutas on the Neolithic and Copper Age settlements of southeastern Europe and particularly her explorations into the feminine forms of the period as possible expressions of Goddess worship have implications for the material culture of the Indian subcontinent in ways that have perhaps not been adequately addressed. Equally, insights into some of the surviving trajectories of rituals and iconographies of goddess worship might serve to throw more light on enigmatic aspects of archaeological finds including from the Neolithic, not just in the context of the subcontinent but elsewhere in antiquity. The paper also sets out to explore the place of the dancing form in ritual particularly with respect to goddess worship, which emerged as a more distinctive feature of Indian antiquity than in many other parts of the world.
\end{abstract}

Keywords: Goddess, Neolithic, Harappan, South India, Dance, Ritual.

Indijos subkontinentas yra vienas iš pasaulio regionu, kuriame deiviu garbinimas išliko ilgiausiai. Kertiniu Marijos Gimbutienes darbu apie neolito ir bronzos amžiu gyvenvietes pietryčiu Europoje reikšmè materialiai Indijos subkontinento kultūrai iki šiol nebuvo pakankamai dèmesingai akcentuota. Ypač reikšmingos moters figūrèlių kaip galimos deivès garbinimo išraiškos studijos. Be to, kai kurie išlikę deivès garbinimo ritualai ir ikonografija galètu padèti atskleisti iki šiol neišaiškintus neolito laikotarpio archeologiniu radiniu aspektus, ir ne tik subkontinento, bet ir Antikos kontekste. Šiame straipsnyje taip pat tyrinèjama šokio judesio forma ritualuose, ypač susijusiuose su deivès garbinimu. Šokis, kaip iš senovés atkeliavęs ypatumas, Indijoje matomas ryškiau nei daugelyje pasaulio vietų.

Reikšminiai žodžiai: deivè, neolito laikotarpis, Harapa, pietų Indija, šokis, ritualas.

\section{INTRODUCTION}

Gimbutas argued that the southeastern and eastern Europe settlements of the Neolithic and Copper Age of about $6000 \mathrm{BCE}$, which preceded the advent of Indo-European cultures, constituted a distinctive civilizational grouping with prominent feminine representations, akin to a goddess worshipping 'Old Europe' (Gimbutas 2006; Spretnak 2011). She dwelt on the abundance of anthropomorphic and zoomorphic figurines, mostly female, which could have been linked fertility cults. A certain pride of position for the feminine, with regards to ritual ceramics and egalitarian burial patterns, and the relative absence of weapons of warfare were marked differences from later Bronze Age cultures associated with the advent of Proto-Indo-European speakers from northern Europe with horses; which Gimbutas particularly highlighted (Spretnak 2011). The ideas of the Lithuanian archaeologist Gimbutas, even if contested, are relevant to the Indian subcontinent (notwithstanding the unresolved enigmas of early urban civilization of the Indus region and its yet undeciphered script), while 
Lithuanian is the Indo-European language closest to Sanskrit, at the root of many languages of the Indian subcontinent. Despite divergent views, the dominant consensus remains that certain threads of longstanding continuity may be discerned going back to the pre-Harappan Neolithic (Jarrige 1993; Possehl 2002, 23) and the Mature Harappan in Pakistan and northwestern India in terms of material culture or ritual aspects of the Indian subcontinent at large. Even as the migrations of the Steppe pastoralists seem to have wrought new directions with the preponderance over time of Vedic Sanskrit as the language of ritual mediation, there were apparently significant assimilations from earlier cultures.

Thus, while this paper explores the significance of some early figural depictions of the feminine from the north-western Indian subcontinent, it also touches upon lesser known aspects from southern Indian prehistory. The links to later trajectories are explored whereby, particularly in southern India, goddess worship became very entrenched, along with dance in sacred ritual, although not necessarily in inter-linked ways.

\section{THE 'VENUS’ AND ‘GODDESS’ IMAGERY OF EUROPE AND ASIA MINOR}

Female 'Venus' figurines appear very early in Paleothic Europe such as the Malta Venus (Gerasimov 1964) from Upper Paleolithic Siberia (23000 BCE), in mammoth ivory and reindeer antler. Links with fertility may be discerned in examples such as the Willendorf Venus (23000 BCE) and the Konstenki Venus, 17000 вCE, Russia, that portray pregnant women with a full belly and breasts. Such figures continued into the Neolithic including the 'red-haired goddess' from Deronje, Serbia, c 6000-5500 все (Gimbutas 2001, 7; Becker 2007), one of the largest prehistoric figurines at nearly $40 \mathrm{~cm}$. Examples are also found from the Neolithic Halaf culture (Fig. 1) of Mesopotamia and Syria of c 6000-5100 BCE (Campbell 1992; Akkermans, Schwartz 2003, 143).

The continuity from the Paleolithic to the Neolithic of not only votive female figurines but also aspects of anthropomorphic and zoomorphic symbology representing fertility, as associated with the 'mother goddess' was explicated by Gimbutas (1991; 2006). These include anthropomorphic birds from Paleolithic Mezin in Siberia with a large posterior and V-shaped marks identified with the vulva (Gimbutas 2006, 3). At the Neolithic site of Catal Huyuk in Anatolia, the placement of skeletons following vulture excarnations has invited comparisons with a foetal position in a wombshaped grave signifying the wait for rebirth. The bucrania of the horned bull's head was thought to signify the womb (Gimbutas 2006; Nagappa 2020) and also seems to appear in various zoomorphic representations such as a Neolithic 'bird woman' with the arms depicted like bull's horns. Gimbutas (2001, 55-71) referred to the symbolism of the 'womb-tomb', although such notions have had their detractors. At Göbekli Tepe (c 9800-9600 вСE), the vulture stone depicts both a birth-giving goose as well as a flesh-devouring vulture, which seem to signify the life-cycles of birth and death (Nagappa 2020). The notion that the bull head signified the uterus with fallopian tubes (Nagappa 2020) makes an underlying assumption that female carcasses would have been observed for anatomical detail. The term Göbekli is said to refer to the navel in Turkish. Although there may be various interpretations of such motifs which can be debated, the kind of analyses begun by Gimbutas and taken further by Nagappa do have significance in terms of providing new pathways to interpret or explore pictorial and figural and faunal motifs in prehistory.

The well known seated woman of Catal Hoyuk (Caubet 2019, 33) with two felines depicts a nude female form: with the breasts and the shapes of the shoulders seemingly conjuring the form of a bull's 
Fig. 1. Sketch of female figurine from Mehrgarh, Period IV, Baluchistan, $c 3000$ BCE (after Jarrige 1988, 65). Courtesy Udaya Kumar.

1 pav. Moters figūrèlès, aptiktos Mergarhoje, brèžinys. Mergarha, IV kultūrinis sluoksnis. Beludžistanas (pagal Jarrige, 1988). Skelbiama sutikus Udaya Kumar.

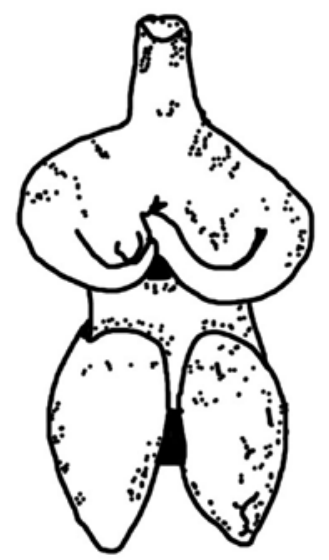

Fig. 2. Sketch Neolithic figurine from Halaf culture (c $6000 \mathrm{BCE}$ ), Musee de Louvre. Sketch courtesy Udaya Kumar.

2 pav. Neolito laikotarpio Halafo kultūros moters figūrèlès, aptiktos Europoje, brèžinys. Luvro muziejus. Skelbiama sutikus Udaya Kumar. head. Such motifs from Asia Minor and Anatolia seem to have spread to the Mediterranean and Mesopotamia. The Babylonian goddess Ishtar was depicted with a feline, as was the Roman goddess Cybele of Troy of Anatolian origin (Walker 1983; 2000; Sircar 2016). Bull sacrifice or taurabolium was part of a specific Roman cult associated with the worship of Magna Mater or the mother of the gods.

\section{FEMALE FIGURINES FROM THE}

\section{PRE-HARAPPAN NEOLITHIC, HARAPPAN AND BEYOND}

Clay and terracotta images from Neolithic Mehrgarh in Baluchistan in Pakistan from sites such as Zhob echo aspects of the prototypes of 'goddess figurines' from $7^{\text {th }}$ millennium Neolithic Europe and Turkey. While the earliest were of unbaked clay, baked clay or terracottas came into vogue at Mehrgarh from the $5^{\text {th }}$ millennium BCE. However, as pointed out by Kinsley (1987) the early female figurines of Europe seem more closely linked to fertility as conveyed by the representations of pregnant women and reproductive organs. This also seems to be the case with early Anatolia.

On the other hand, the emphasis in the clay figurines from Neolithic Baluchistan were on adornment, with prominent head-dresses, jewellery, and clothing details. Even so, there are some terrracottas with similar depictions of seated figures with voluptuous breasts and thighs along with detailed ornamentation. These included three seated statuettes from Mehrgarh Period IV (Jarrige 1988, 65-70) with elaborate coiffures and a long scarf akin to the modern day dupatta of northwestern India, just above the prominent breasts. Indeed, a couple of images (such as Fig. 2) from Mehrgarh Period IV strikingly resemble the bird woman anthropomorphs from Neolithic Europe (eg Gimbutas 1974, 163); and more particularly the Halaf Culture with exaggerated thighs and arms below the breasts (Fig. 1, 2). The image with hands below the breasts harks back to female anthropomorphic figures such as a vase from Romania (ibid., 163). There is also a standing female figurine with simpler hairdo holding a child which might have been linked to fertility rites.

What markedly carries over from the Neolithic into the Mature Harappan at sites such as Mohenjodaro and Harappa in Pakistan are the 'Standing Mother Goddess' type of figurines with some parallels in Mesopotamia. The typical Harappan mother goddess figurines depicts a seminaked slim woman with rather pinched breasts, with a prominent waistband or girdle and a prominent fan-shaped headdress, sometimes with appendages (Fig. 3). The numerous and rich recently-excavated 


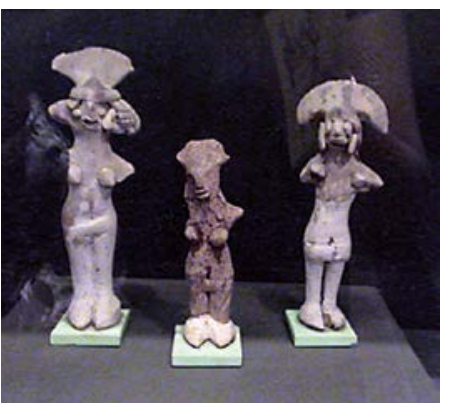

Fig. 3. Harappan standing 'mother goddess' figurines, British Museum. Photo by Sharada Srinivasan.

3 pav. Harapos kultūros stovinčios deivès Motinos figūrèlès. Britų muziejus. Sharada Srinivasan nuotr.

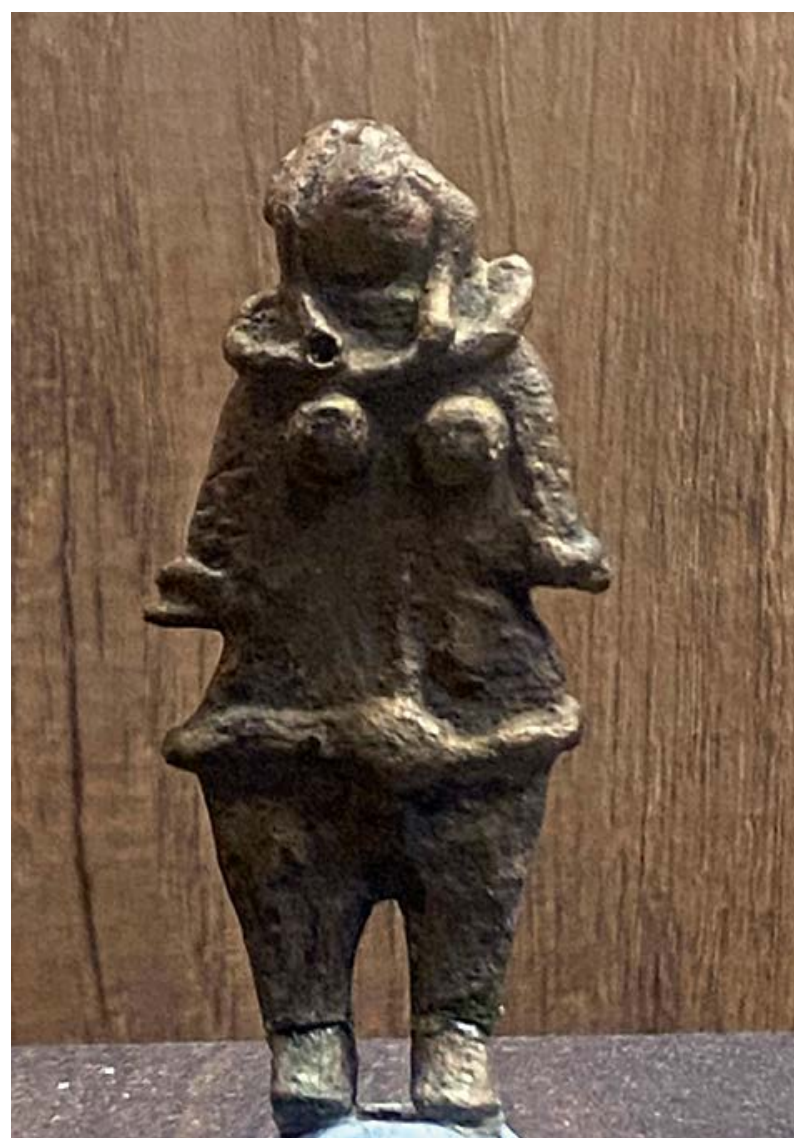

Fig. 4. Mother Goddess figurine from Adichanallur, Tamil Nadu, с 800 вCE. Photo by Sharada Srinivasan.

4 pav. Deivès Motinos figūrèlè, aptikta Adichanallur archeologinèje vietoveje, Tamilnadu. Apie $800 \mathrm{~m}$. pr. Kr. Sharada Srinivasan nuotr.

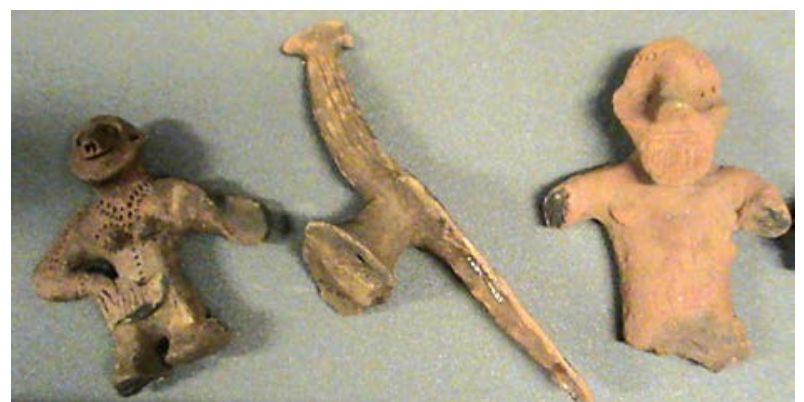

Fig. 5. Pottery assemblages from the Nilgiri Cairns, Tamil Nadu, British Museum. Photo by Sharada Srinivasan, courtesy Richard Blurton.

5 pav. Nilgirio vietovès keraminių dirbinių rinkinys, Tamilnado. Britu muziejus. Sharada Srinivasan nuotr., skelbiama sutikus Richardui Blurtonui.

Mature and Late Harappan sites from north-western India at Rakhigarhi, Banawali, Kalibangan and Dholavira, seem, somewhat surprisingly, to have fewer such terracotta finds.

However, a remarkable parallel in metal with Harappan mother goddesses is found in the enigmatic Iron Age/'megalithic' of deep peninsular India. Iron Age Adichanallur in Tamil Nadu in southern India yielded a metal figurine (c 800 BCE) with marked similarities to Harappan mother goddess terracottas, in the headdress and sash (Fig. 4). Recent carbon dates for Sivagalai in Tamil Nadu go back to the end of the $2^{\text {nd }}$ millennium вCE. Significantly, one of the languages of Baluchistan, Brahui is a surviving North Dravidian language (Parpola 1988) with discernable connections with the Dravidian languages of southern India such as Tamil. One explanation for this has been the likely migration from the Indus region further south after the decline of the Mature Harappan civilisation. The terracottas uncovered from the enigmatic Iron Age cairns of the Nilgiri Hills in Tamil Nadu also provide some intriguing comparative aspects. Apart from lively bird and animal finials, a female torso not unlike a mother goddess figurine was uncovered, as well as a bearded male figure with a diadem, distantly 
echoing the Harappan bearded priest king from Mohenjodaro (Fig. 5). Gold diadems have also been found from Adichanallur. The indigenous Nilgiri communities of the Todas, Kotas and Badagas speak distinctive languages as part of the protoDravidian or Dravidian group, with some words being comparable to Sumerian according to some scholars (Paul Hockings pers comm). Kota women typically wear their hair in a sideways bun or Kolkot akin to the Gonds (another group of proto-Dravidian speakers) and reminiscent of the hairstyle of the well known Harappan Dancing Girl figurine from Mohenjodaro. Kota priests also knot their hair and wear their tunic over their shoulder, aspects which recall to Harappan styles. Amongst the artisanal communities of the Kotas, it is the women who are potters, involved in both hand-made and wheelturned pottery. The contemporary coarse wares of Kota pottery are not dissimilar to the pottery from Nilgiri cairns (Naik 1966, 149; Hocking 1975). This provides an interesting point for speculation with respect to early Neolithic and proto-historic pottery, that the creators of several female figurines might themselves have been women, which might explain the predominance of female forms.

Interestingly, Mortimer Wheeler $(1953,109)$ observed that the 'mother goddess' terracotta had no clear counterpart in the seals or the sculptures found and could have represented a household cult rather than something more organised as with similar figures in west Asia going back to considerable antiquity.

Whereas the pre-Harappan and Harappan repertoire of clay female figurines seem less correlated to fertility imagery compared their western counterparts, they also appear benign, and hence seemingly uncorrelated to the powerful martial goddesses that became popular in the Indian subcontinent. Their closest antecedents in the art of the subcontinent, though with a wide hiatus, seem to lie in the Yakshi images, the benign and alluring tree nymphs with an elaborate headgear and prominent belt which surface by the $3^{\text {rd }}$ century Mauryan period in terracotta and other media. The Yakshi images do have a connotation with fertility, bounty and rites of birth as seen in the image of the Shalabhanjika (Sanskrit), the maiden who bends the Shala tree branch. She prominently features in the sandstone gateway of the $3^{\text {rd }}$ century BCE Mauryan Sanchi stupa flanked by an elephant related to the birth of the Buddha and his mother Maya's dream of a white elephant. A Harappan seal depicts a plant sprouting out of an upside down figure which could relate to the womb (Rao, Plate XXIV D). In its almost insect-like composition, it also brings to mind the 'bee-goddess' depiction on pottery described by Gimbutas (1974, 184) from Romania of the 5 th millennium вCE. The iconography of the goddess known as Lajjagauri from early medieval southern India such as Chalukyan art consists of a sunflower in place of the head of a nude female figure with an exposed vulva. Thus, an analogy with broader primeval fertility cults such as from early European or Anatolian prehistory may be speculated upon.

\section{NEOLITHIC SANGANAKALLU, AUDIO-VISUAL PERFORMATIVE SPACES AND INDUS SIGNS}

In the Bellary region, of the southern state of Karnataka, amidst hillsides drastically denuded by quarrying and blasting with dynamite for the granite sought for construction, some dolerite dykes have survived which preserve a remarkable remnant of humanity's cultural legacy. The hillock of Hiregudda, near the villages of Sanganakallu and Kupgal, hosts an astonishing and diverse array of man-made 'cupules' or depressions made by some of south India's earliest settlers around 3000 BC. When struck, these give off a range of tonalities and percussive sounds, with a metallic ring akin to the sound of the clay pot or ghatam used in the southern Indian Carnatic 


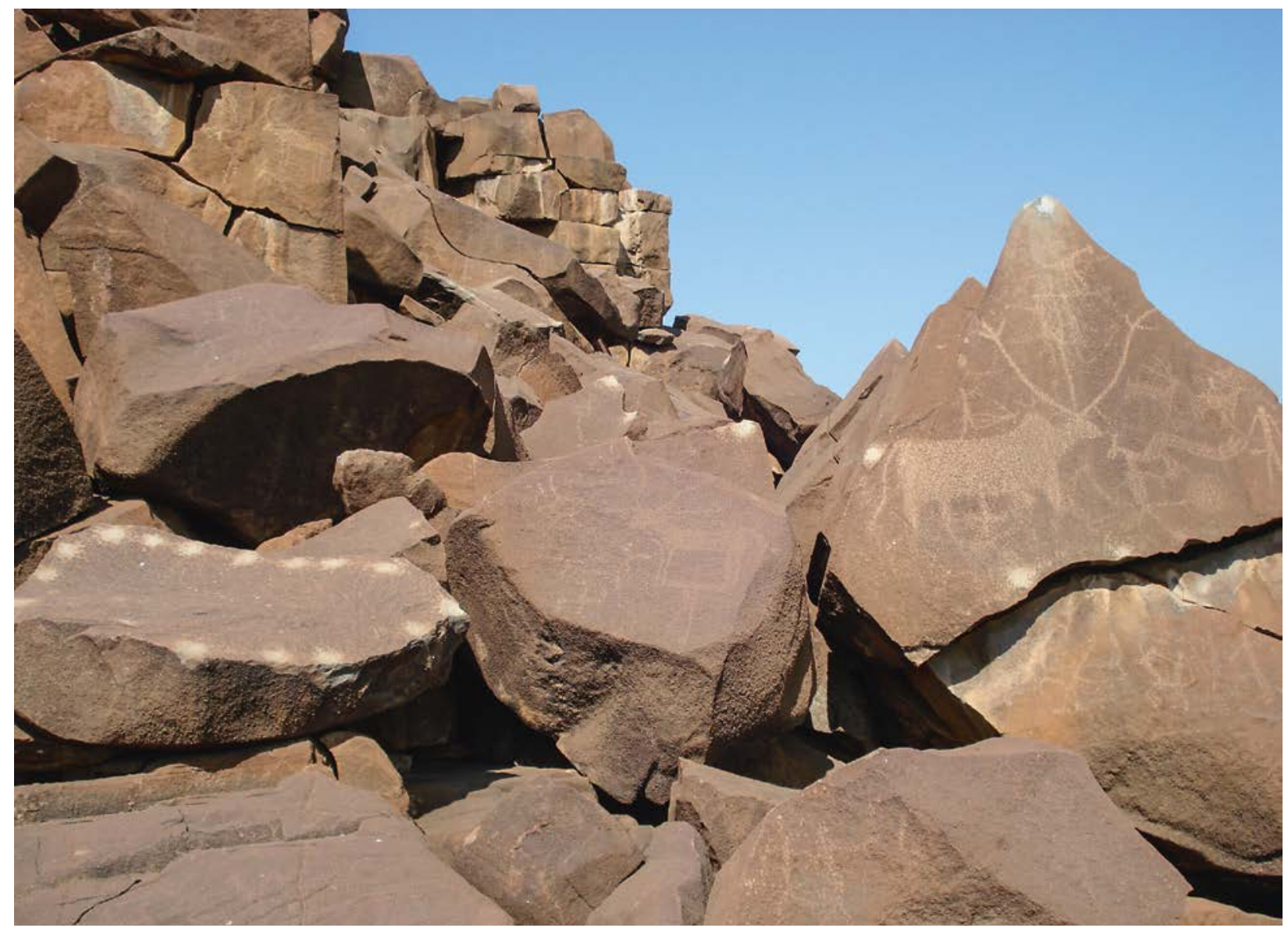

Fig. 6. Sanganakallu, massif with lithophone of rock cupules and pictographs of humped cattle. Photo by Sharada

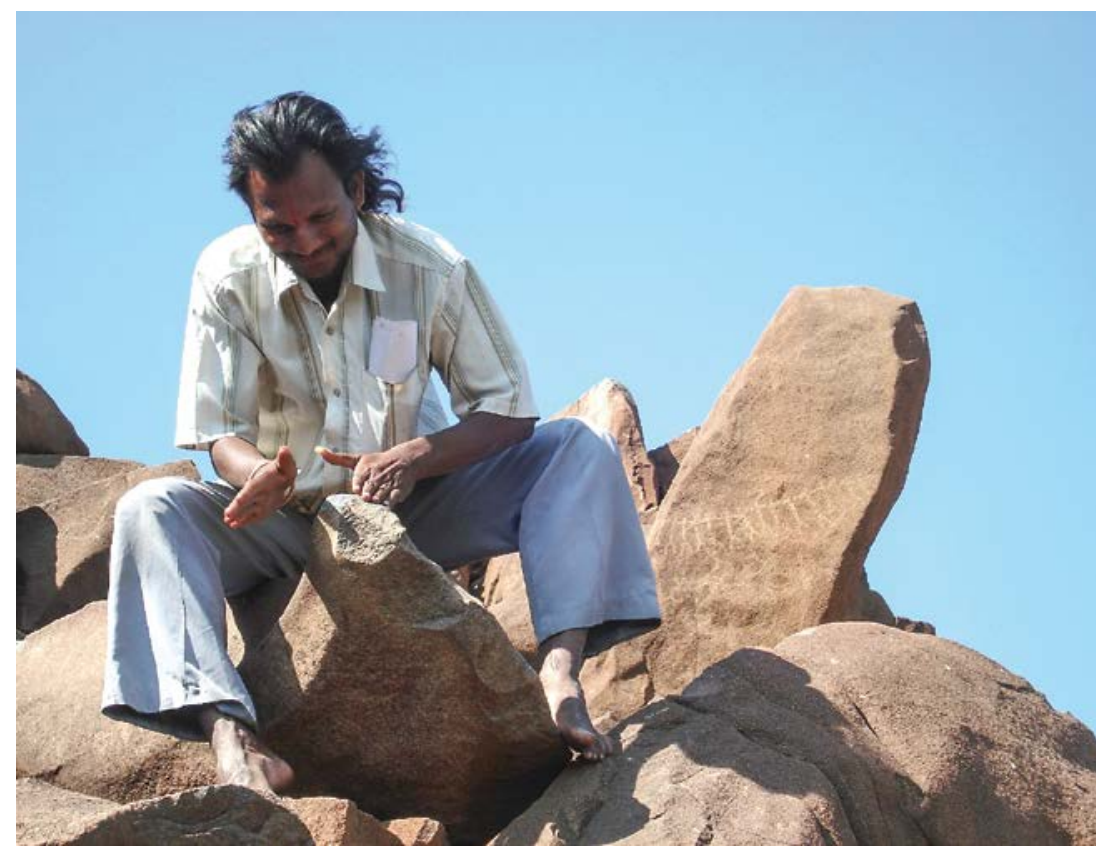
Srinivasan.

6 pav. Akmenų masyvas, kuriame apskritomis žymèmis išsiskiria litofonas, taip pat matoma kuproto galvijo piktograma. Sanganakallu archeologine vietovè. Sharada Srinivasan nuotr.

Fig. 7. Sanganakallu, menhir-like rock with line of dancers and with rock cupule below. Photo by Sharada Srinivasan.

7 pav. Menhyro formos akmuo, ant kurio matyti eilè šokèjų. Žemiau dubenuotasis akmuo. Sanganakallu archeologinè vietovè. Sharada Srinivasan nuotr. 


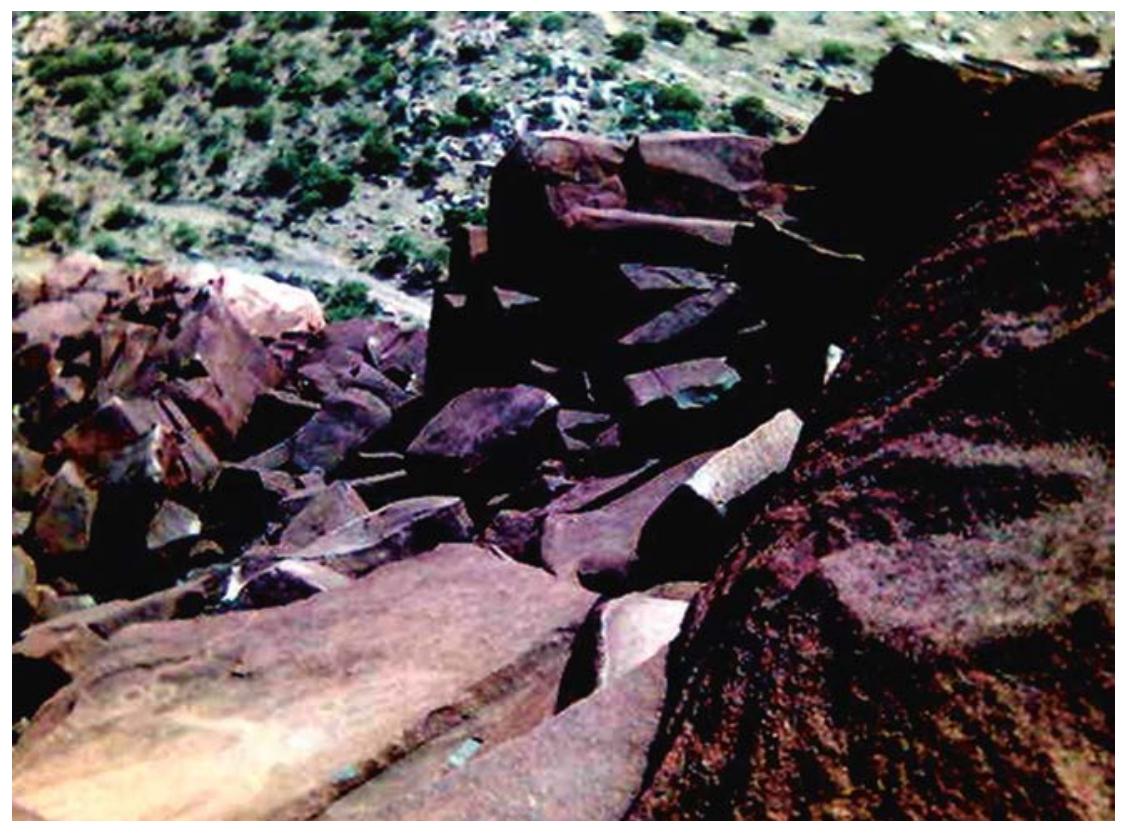

Fig. 8. Sanganakallu, rock art of large female figure. Photo by Sharada Srinivasan.

8 pav. Ant akmens - didelè moters figūra. Sanganakallu archeologinè vietovè. Sharada Srinivasan nuotr. music repertoire. Both the rocks and the ghatam are played with the fingers and palms.

The patination of the cupules also suggested considerable antiquity. What is astonishing is the visual integration of the percussive rocks and the location of the cupules to the rock art in such a way as to convey very distinctive audio-visual experiences. For example, the rock faces of an open air plateau are richly covered with figural rock art bruisings, while at the base is a flatter cuboid-shaped rock with cupules all along the edges which could have been used for group performance (Fig. 6). A pyramid-shaped rock bore a petroglyph of a humped bull with spectacular horns, a prominent peacock with elongated plume and a few human figures with well-placed cupules at the apex and vertices. This configuration was such that a person could sit at the rear of the rock and play the cupule with the bull petroglyph below and a panoramic view of the plains. A menhir-like rock had rock art in white showing a serpentine line of dancers with linked hands, while just below was a boat-shaped rock with a prominent cupule at one end so that a person could sit and play it against the backdrop of the rock art of dancers (Fig. 7). Such depictions could also have been connected with mating rituals and related dances. One is also reminded of the dances with linked hands that were performed by indigenous tribes such as the Gonds, Santals and Warli Adivasis in Central India and peninsular India amongst others. At one spot below the cliff face, one could discern a large female figure in white on a flatter elongated rock of several feet (Fig. 8). Her prominent size compared to other more dimunitive examples of rock art conveyed implications of ritual veneration.

Bull imagery in the cultural and ritual landscape of rock art sites at Sanganakallu and the Rayalaseema region could suggest the prevalence of fertility cults among the early agricultural communities (Korisettar, Prasanna 2014). It brings to mind the humped zebu cattle which are well depicted at Neolithic Mehrgarh (Possehl 2002, 27). A rock art pictograph of a tiger was also observed by the author in Maski in north Karnataka.

At Sanganakallu, there was also a prominent artwork of an endless loop motif on a cliff face (Fig. 9), reminiscent of ephemeral ritual Kolam patterns 


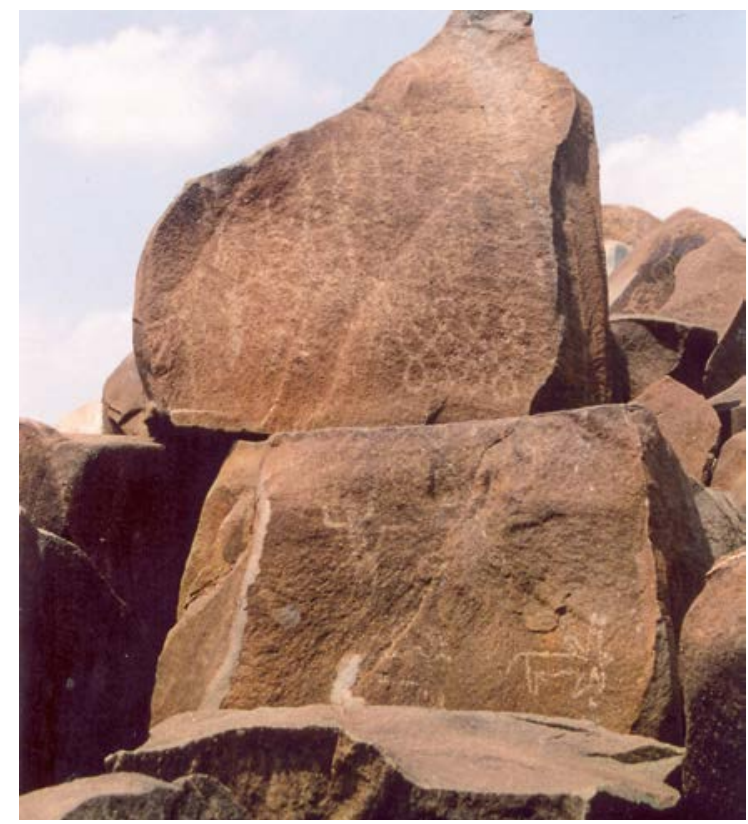

Fig. 9. Sanganakallu, rock art of Kolam type 'endless' loop pattern. Photo by Sharada Srinivasan.

9 pav. Ant akmens - Kolam tipo „nesibaigiantis“ mazgas. Sanganakallu archeologinè vietové. Sharada Srinivasan nuotr.

women make in Tamil Nadu on thresholds using rice flour around a grid of dots. Such 'kolam' style patterns are also discerned on a couple of Harappan seals (Kenoyer 1998, 195). It is interesting too that the Kolam type motif occurs on three identical Harappan tablets from Mohenjodaro (Joshi, Parpola 1987, 115; Priyanka 2003; sketch in Fig. 10). These also feature a figure, perhaps a woman, kneeling before a tree and holding a $\mathrm{V}$-shaped sign. This also recalls the fertility motif of the tree nymph discussed before. The V-sign seems particularly interesting when seen in the light of the connections made by Gimbutas of V-shaped signs from Neolithic figurines of birdwomen anthropomorphs with the vulva as mentioned before. A motif of a circle with four spokes was also detected by the author at Sanganakallu next to a couple. At Neolithic Mehrgarh, c 6000 BCE a tiny wheel-shaped amulet with six spokes was uncovered, probably the oldest known lost wax copper casting (Thoury et al. 2016). This motif is also seen in the Indus script as part of a white gypsum signboard from Dholavira from Gujarat, as well as in various miniature seals and clay tablets.

Rock art pictographs and signs found at a site near Hampi are reportedly connected to the Harappan script. It has been conjectured that they were related to the dialect of the Gonds and worship of their goddess Kotamma (Malagi 2016). The tribal Central Indian communities are known for the prevalence of horned dances and deities. Prominent Indus seal motifs are of horned humans or humanoids as pointed out by Possehl (2002, 5860). Rock art from Melumalai in the Krishnagiri district of Tamil Nadu is also reported to have links to IVC motifs (Selvam 2021). These include motifs

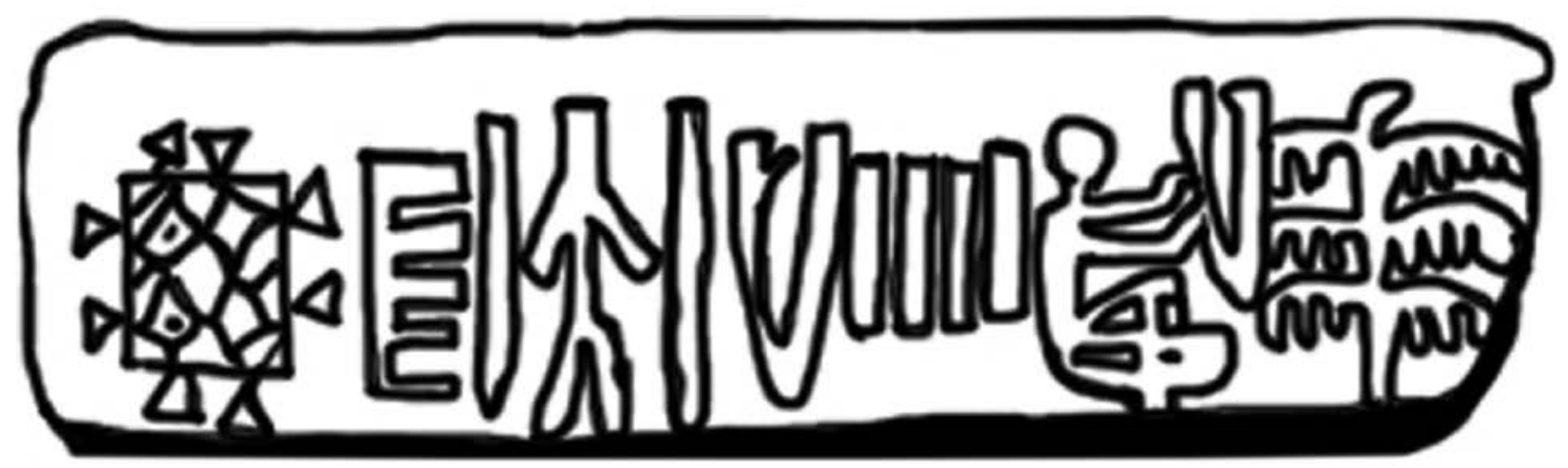

Fig. 10. Sketch of Harappan seal showing Kolam pattern (after Joshi, Parpola 1987, 115). Sketch by Udaya Kumar. 10 pav. Kolam tipo nesibaigiančio mazgo brěžinys ant Harapos kultūros antspaudo (pagal Joshi, Parpola 1987, 115). Udaya Kumar brėž. 
in white of three leaves and circles with six and four spokes. Two dancers holding hands with the other hand on the hip are also seen and are reminiscent of Sanganakallu. Recent excavations at the site of Keeladi, along the Vaigai river near Madurai have unearthed evidence for urbanised features going back to the $6^{\text {th }}$ century вСE according to ${ }^{14} \mathrm{C}$ dating, including evidence of ring wells and paved streets. A large potsherd with a few signs similar to IVC ones were also found (Isaac 2019). Though tenuous, it is nevertheless worthwhile to point out probable links to such material culture. With respect to a word in a Sumerian tablet which seems to refer to the Indus, i.e. Meluhha, Possehl $(2002,62)$ points out that the Vedas mention the mlecchas who spoke incomprehensible languages other than Sanskrit. Interestingly, 'Meluhha' has certain overtones that are more reminiscent of Tamil place names than anything else to this author. 'Mel' implies lofty, and place names with this word include Melur/Meluru, (ie a town at a height) which is in the Nilgiris while Melumalai refers to the high mountain.

\section{ENDURING IMAGERY OF MARTIAL GODDESSES}

The most marked parallel between Harappan and Near Eastern glyptic art is of the 'contest' motif, whereby in Mesopotamian art, fights with lions or bulls are frequently depicted, as pointed out by Parpola (1994, 246-247). A prominent depiction amongst Harappan seals is of a figure grasping two tigers by the throat, one in each hand, with six dots around the head reminiscent of the six locks associated with Mesopotamian heroes. Yet another interesting depiction is found in a planoconvex moulded tablet (Fig. 11) found in 1995 in Mound ET at Harappa and discussed by Kenoyer (1998). The convex side has a vertical depiction of a similar figure in combat with two felines with a six-spoked wheel-shaped sign above and an elephant below. The flat side has a horizontal depiction, which Kenoyer (1998, 114-115) pointed out was of a person impaling a buffalo with a spear while pressing its head down with a leg, with a crocodile above and an adjacent horned deity in a yogic position. He adds that water buffalo sacrifice is reminiscent of the worship of the goddess Durga in later Hindu ritual. Possehl (2002, 59-60) pointed to connections between the Sumerian portayals of Gilgamesh gripping his lions and the semi-bovine Sumerian Eabani or Enkidu. The positioning of the crocodile is also interesting, bringing to mind as it does the depiction of the reptilian salamander in the Göbekli Tepe friezes and in terms of the broader possibilities of faunal symbology.

The martial goddess, mostly widely known as Durga, is one of the most formidable and widely worshipped in the Hindu pantheon, typically depicted riding into battle on a lion. Often she is depicted as defeating the buffalo demon Mahisha and is known by the epithet Mahishasuramardini. Kinsley $(1987,95)$ pointed to the lack of parallels for martial goddesses in the Vedic corpus of about 1500 BCE. Vedic goddesses appear more as personifications of natural phenomena, such as Usha or dawn with twenty hymns, Saraswati as the mighty river goddess (whose worship endures in the subcontinent) and Prithvi the earth goddess, and they seem to have a subordinate status to the male gods such as Indra and Agni. On the other hand, goddesses who have prevailed in later day popular worship as independent and powerful deities such as Durga and Kali in Puranic lore and Brahmanical Hinduism, do not have prominent Vedic equivalents and instead, show threads of continuity with IVC (Indus Valley Civilisation) related pre-historic and protohistoric motifs.

Myths of Durga slaying Mahisha came to the fore in Puranic lore from about the Gupta period when the Devi Mahatmya is thought to have been compiled. Prominent depictions include a beautiful 


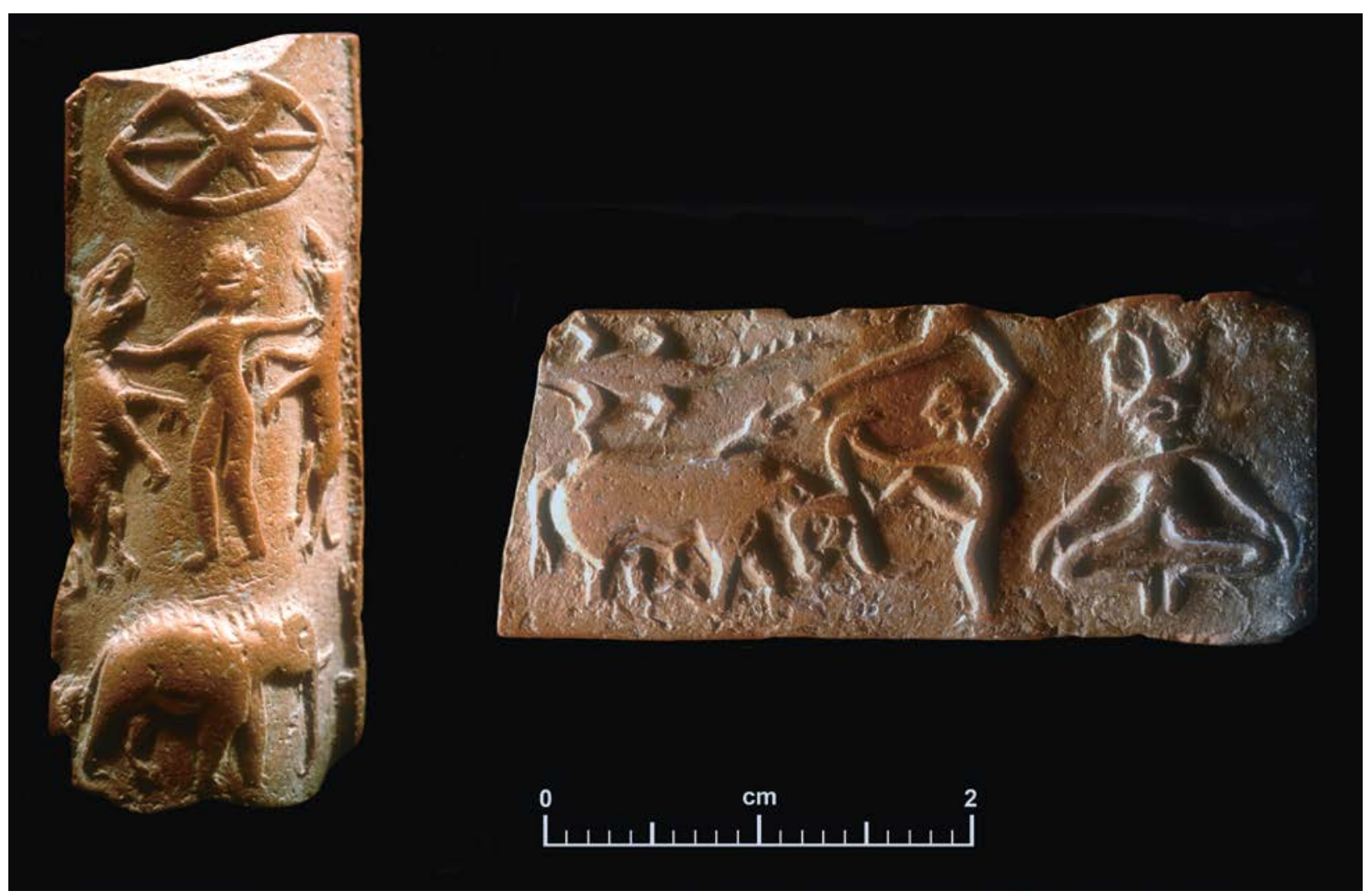

Fig. 11. Terracotta table from Harappa, Pakistan, H95-2486. Photo courtesy of the Harappa Archaeological Research Project and Department of Archaeology and Museums, Govt. of Pakistan, Courtesy Jonathan Mark Kenoyer.

11 pav. Terakotos lentele, aptikta Harapoje (H95-2486). Pakistanas. Skelbiama sutikus Harapos archeologiniu tyrimu projektui ir Pakistano Vyriausybès Archeologijos ir muzieju departamentui bei Jonathan Mark Kenoyer.

large-sized $7^{\text {th }}$ century copper alloy image in worship in a temple in Chamba in Himachal and the depiction of the celebrated $7^{\text {th }}$ century Pallava stone friezes of Mahabalipuram. Kinsley (1987) opines that she is likely an earlier or indigenous deity outside the framework of Vedic lore. Durga is associated with the Vindhya mountains in the Mahabharata epic, where several indigenous communities including adivasis have lived (Vasudevan 1990).

A seal motif from Mohenjodaro (published in Kenoyer 1998, 193) has been identified by Krishna $(2012,139)$ as a woman sitting on a branch of a tree, identified by her as acacia, with a tiger looking back which she suggests could be an early depiction the martial goddess accompanied by the tiger, later known as vahana or vehicle. Although Possehl (2002, 60, Fig. 3.3) describes the figure as a male, the knotted hair and the posture lends strength to Krishna's identification of the figure as a female. The author, as a person trained in the classical south Indian dance form of Bharata Natyam, is also struck by the dance-like posture with a knee up, and one hand as if beckoning with a gesture. In Bharata Natyam too, the goddess and tiger are depicted as looking at each other (see https:// www.youtube.com/watch?v=8WqkqgluQkw; 5.48). Krishna (2012) also points to the significance of the worship of the ancient martial goddess of the Tamil region, Kottravai. She is mentioned in Tamil Sangam anthology dated to $300 \mathrm{BCE}$ to $300 \mathrm{CE}$ including the 
Pattupattu. Of the five geographical tracts or tinai which were used in poetic metaphor, Kottravai is the goddess of palai or the wasteland, which included semi-nomadic hunters known as the Eyinar. Kottravai as the goddess of war and victory was also appeased by blood sacrifice. Tiwari (1971) suggests that there is no marked element of fertility in her worship in Tamil heroic poems and the associations are more martial. In the steles found in rural Tamil Nadu and at the Pallava Mamallapuram rock-cut excavations of the $6^{\text {th }}-7^{\text {th }}$ centuries she is often shown carrying a prominent body length bow or villu associated with hunters such as the Maravas. Interestingly, she also stands poised on a beautifully crafted buffalo head in many Pallava and Chola depictions akin to Anatolian bucrania. Bull heads are also depicted along the recently-excavated chariot burial from Sinauli, $c$ 1900 вCE in Uttar Pradesh in northern India probably of the late Harappan period.

Kinsley $(1987,176)$ points to the similarity of Kotavi to the south Indian Hunting goddess Kottravai. Kotavi is a goddess associated with battlefields who is sometimes included amongst the matrikas and is described in the Vishnu purana as a wild, nude goddess who haunted the battlefield. Interestingly, a goddess by name of Kottari Devi is also said to have been worshipped in Baluchistan, at the Hinglaj Mata temple in a cave in the rocky terrain of Lyari Tehsil (Pandey 2020). As mentioned before, Brahui, spoken in pockets in Baluchistan has proto-Dravidian roots and the connections with the Dravidian language group of peninsular and southern India including Tamil. This had added fuel to the theory that there were migrations from Northwestern India into southern India after the decline of the Harappan civilisation carrying certain aspects of material culture. We have also mentioned the similar sounding Gondi goddess Kotamma. While the term Durga also means fortification, it is interesting that Kottai in Tamil likewise refers to a fort. Kotda or Kot is also used in Rajasthan and Gujarat to refer to a fort, while an important Harappan site in Pakistan is Kot-diji in the Rohri Hills. Possehl $(2002,72)$ points out the Kot-Diji means 'daughter of the fort', and that there was an early Harappan fortification at Kot-Diji. The pre-British name for Quetta in Baluchistan is Kotta which in Brahui also means fort (Saleem Jahangir, Brahui speaker, pers. comm).

Although numerous Pallava sculptures are linked to the northern deities of Durga and Mahishasuramardini, who slays the buffalo demon, Charlotte Schmid (2011) suggests that the Pallava goddesses derive from more distinctive earlier traditions of worship of Kottravai. Freestanding $6^{\text {th }}$ to $9^{\text {th }}$ century steles are found such as in Villipuram amidst open lands, with the goddess depicted with a discus, conch, dagger and prominent bow. However, the more rustic steles often have the depiction of a deer (maan in Tamil), stag or blackbuck (often charmingly depicted with distinct twisted horns akin to a blackbuck). A Harappan seal motif has five peepul leaves and two stag-like heads (which have also been described as unicorns). Blackbuck was also associated with the Kachi plain of Mehrgarh (Possehl 2002, 27). The more urbane depictions of royal Pallava monuments have the stag replaced by a lion. A frieze in a cave shrine at Mamallapuram also depicts a man holding a knife at his own throat, as if in an act of self-sacrifice or at the very least to cut or bleed himself as blood offering, pointing to a certain ritualisation of self-sacrifice and death, symbolic or actual, associated with the worship of Kottravai, calling to mind the practices of Asia Minor and Mediterranean. Blood sacrifice declined Tamil Nadu from about the $7^{\text {th }}$ century with the spread of monastic Hinduism by Adi Sankara. However, in several places in the subcontinent animal sacrifice has prevailed: such as buffalo sacrifice rites in Nepal, the blood sacrifice in eastern India and Assam associated with worship of the goddess Kamakhya and buffalo sacrifice also in the hill shrine to Kamakhya Devi in remote Himachal Pradesh. Vedic lore, however, 
seemed more preoccupied with horse sacrifice (for which there is also evidence from the Eurasian Steppes), known as Ashwamedha. As pointed out by Younger $(1995,37)$, goddess temples have long been patronised more by the lower castes.

\section{DANCE IMAGERY AND GODDESS WORSHIP}

While this paper has pointed to some parallels in terms of ritual aspects with Old Europe, a striking point of difference with respect to the Indian subcontinent is the importance of dance in ritual. The most iconic Indus Valley figure is the tiny Mohenjodaro 'Dancing Girl' (Fig. 12). This fine lost wax bronze casting depicts a nude girl with one hand on the hip and the other perhaps holding a bowl or a gesture, with the hip in a marked flexion. Her armful of bangles recalls to the shell bangles still worn by Rabaris and other nomadic communities in Kutch, Sindh and Baluchistan, while she also has a prominent necklace with what resembles the shape of carnelian beads, well known from the Indus region. Another bronze female figurine with hand on hip is reported from Mohenjodaro (Kenoyer 1998, 223). Such images have invited comparison with the devadasis or ritual dancers associated particularly with southern Indian temples as seen in $10^{\text {th }}$ century inscriptions of Rajaraja Chola from Thanjavur in Tamil Nadu which mention four hundred dancers attached to the temple. Interestingly, $19^{\text {th }}$ century photographs of hereditary Sadir dancers of Tamil

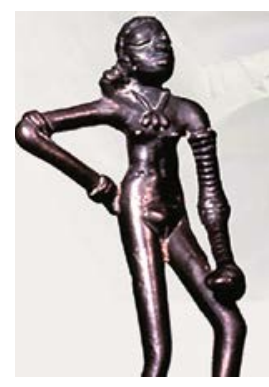

Fig. 12. Dancing Girl figurine Mohenjodaro. Photo courtesy John Marr. 12 pav. Šokančios mergaitès figūrèlè, aptikta Mohendže Daro. Skelbiama sutikus Johnui Marrui.
Nadu show them standing in a similar attitude with the hand on the hip. This posture is found in the present day repertoire of the south Indian classical dance of Bharata Natyam derived from Sadir, while $10^{\text {th }}$ century Chola bronzes of Parvati also strike a bhanga or hip flexion.

However, what is not clear from early pre-historic and proto-historic depictions is whether the goddess herself was associated with dance. In this connection, there is an revealing insight from the Tamil region. Temple worship in the Tamil region from the medieval Chola period is more closely linked to the worship of the male god Siva through the system of Saiva Siddhanta, (which particularly involved the worship of the anthropomorphic dancing form of Siva as a festival processional icon). However, there is interesting evidence that earlier traditions associated with a prominent dancing goddess were subsumed, at the most famous temple of Tillai or Chidambaram associated with the worship of Siva as lord of dance or Nataraja. The etirampalam or opposite Hall later called the Nritta Sabha is linked to legends about Pidariyar or Kali who was patrolling the Tillai forests with her tiger (Younger 1995, 91-92). Legend has it that the goddess entered into a dance contest with Siva, which she lost since she was not able to raise her leg as he does in the urdhvatandava pose on grounds of modesty. Over time her prominence in the complex receded and her most important shrine of Tillai Kali Amman on the outskirts of Chidambaram testifies to her once pre-eminent status. At Madurai in Tamil $\mathrm{Nadu}$, the warrior princess and goddess Meenakshi, is tamed by the male deity Siva or Sundaresan. This points to the overlaying of more patriarchial norms in time over earlier more matriarchial elements of goddess worship.

The dramatic use of dance postures is also seen in Mahabalipuram's magnificent sculpted panel of a many-armed Goddess with a bow and other weapons riding a feline and chasing the buffalo-headed male demon, Mahishasura (Fig. 13) to quell him, which 


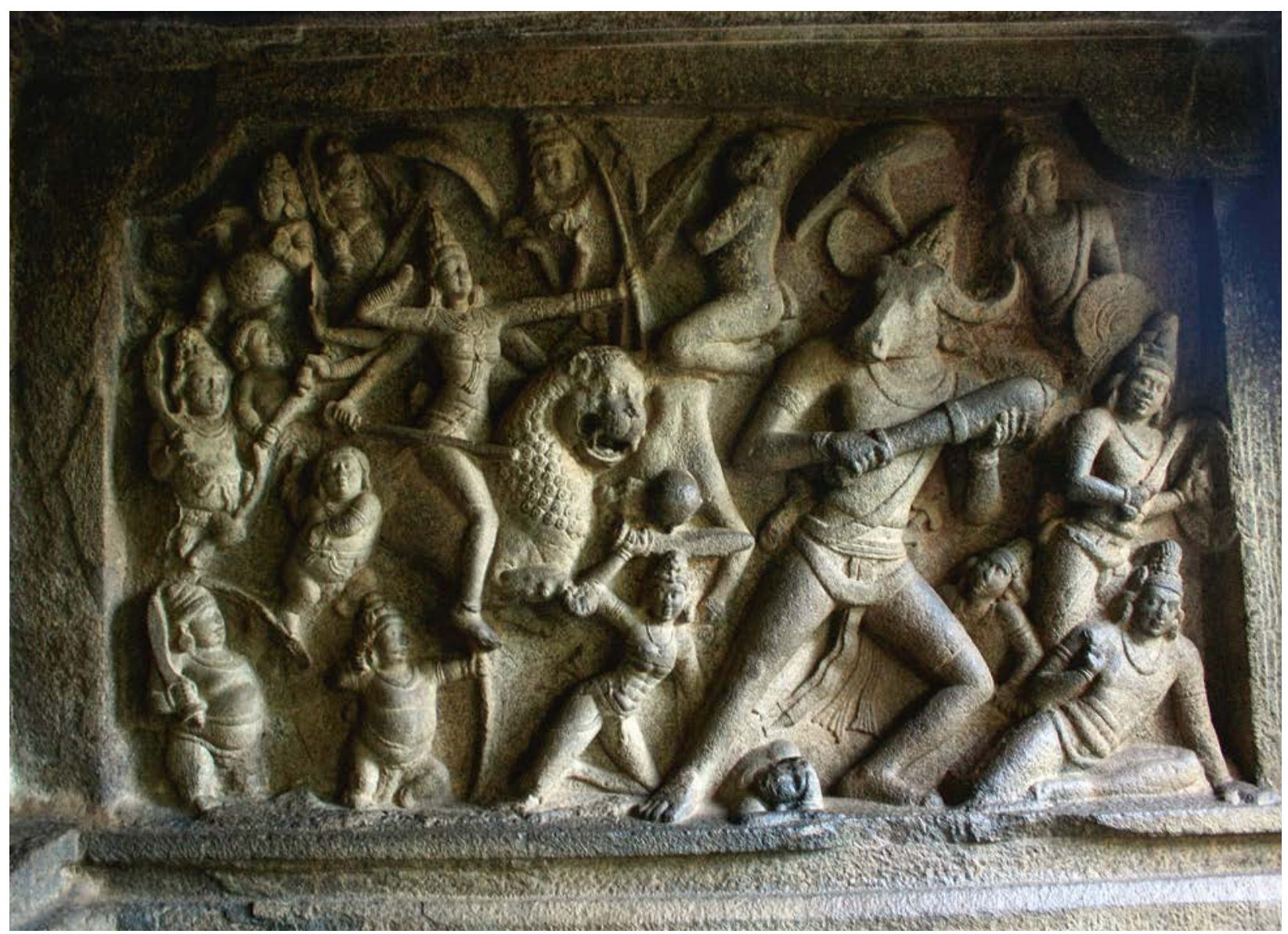

Fig. 13. Frieze of Durga/Kottravai as Mahishasuramardini, the goddess riding a feline destroying the buffalo demon, Mahabalipuram, $7^{\text {th }}$ century, Pallava. Photo by Sharada Srinivasan.

13 pav. Frizas, vaizduojantis deivę Durgą / Kottravai, jojančią ant kačių šeimos gyvūno ir nugalinčią buivolo pavidalo demoną Mahišą. VII amžius. Mahabalipuramas. Pallava. Sharada Srinivasan nuotr.

also brings in a gender dimension. The balletic quality does bring to mind the Harappan tablet with the buffalo being speared. Interestingly, it is this Tamil depiction prominently portraying a buffalo-headed half-male demon (unlike northern versions of Durga which only portray a buffalo), that compares more closely with the Sumerian depiction of the semibovine male figure of Enkidu mentioned by Possehl (2002, 59-60) with respect to Harappan parallels. The Bharata Natyam dance repertoire (Fig. 14) also has riveting items evoking the various aspects of the martial goddess as she takes on the buffalo demon of Mahishasuramardini as Chamundeswari

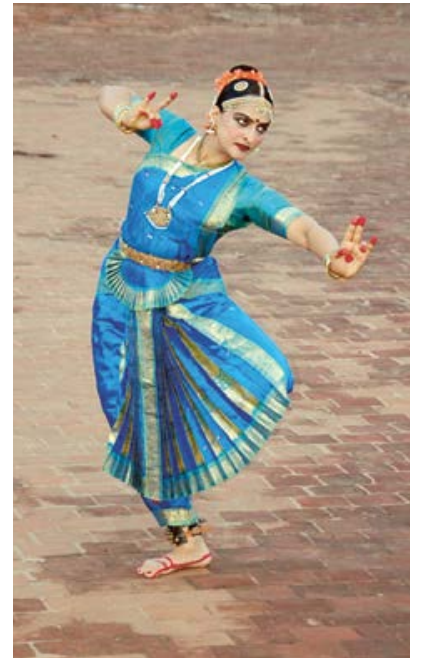

Fig. 14. Bharata Natyam dance repertoire evoking the martial goddess. Photo owner Sharada Srinivasan. 14 pav. Bharata Natyam šokis kovų deivei iškviesti. Sharada Srinivasan nuotr. 


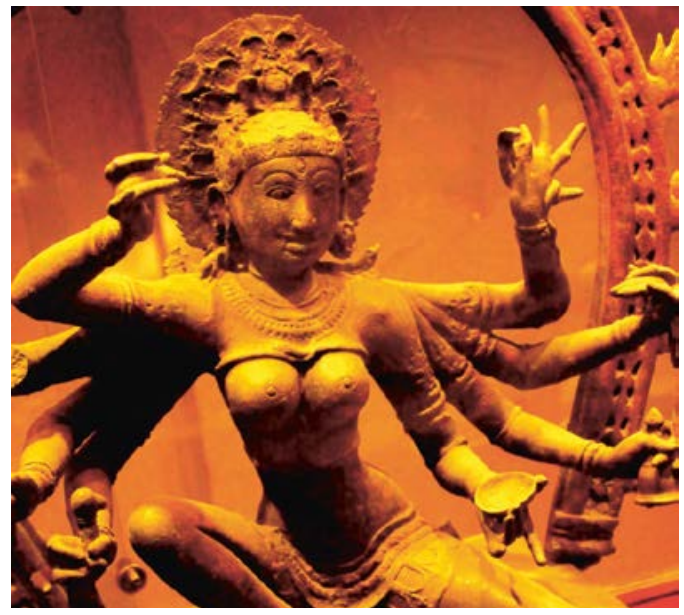

Fig. 15. Bronze image of Goddess Nisumbhasudani, $10^{\text {th }}$ century, Turaikadu, Government Museum, Chennai. Photo courtesy Swaminathan Natarajan.

15 pav. Bronzinis deivès Nisumbhasudani atvaizdas. X amžius. Vyriausybès muziejus, Turaikadu, Čenajus. Skelbiama sutikus Swaminathan Natarajan.

such as Aiyagiri Nandini, while the praise of the Tamil goddess Meenakshi is also part of the dance repertoire.

The author's technical investigations on south Indian bronzes, using lead isotope ratio and compositional analysis had dated a spectacular bronze of Nishumbhasudani (i.e. slayer of the demon Nisumbha) from Turaikadu, Tanjavur district in the Government Museum, Madras to the $10^{\text {th }}$ century Chola period (Fig. 15) (Srinivasan 1996; 1999; 2004; 2016). This splendid and dynamic casting depicts the goddess with eight arms: with one hand holding a mudra related to the classical Indian Bharata Natyam dance repertoire from the Natyasastra of alapadma like an open flower and the other hand holding a cock. It could probably be attributed to the great Chola patron, the widowed queen Semibyan Mahadevi, to whom a fine similar dancing image of the martial goddess Kali in Tiruvelangadu temple is also attributed by Nagaswamy $(1988,156)$. It also resembles a gilt $10^{\text {th }}$ century eight-armed Kali image, similarly seated with a raised knee surrounded by a flame-tipped prabha or aureole (Nagaswamy 1988, 80) from Malangi in Cholaoccupied Karnataka.

The Kerala martial art form of Kalaripayattu traditionally practiced by the matrilineal Nair community had as its most important guardian deity, the fierce aspect of the goddess, Bhadrakali (Zarilli 1998), who possesses boundless powers of destruction or Chamundi. The dynamic use of dance traditions in medieval statuary bronzes, sculpture and painting also owed itself to the fact that many queens as patrons were well-versed in art and dance, such as Chola princess Kundavai, who trained in the Vazhuvur dance tradition (Krishnamurthi 1966, 137). Temple dancers or kuttans and courtesans, who had certain privileges including the owning of property, were also accomplished patrons as seen in records of the Svetaranyesvara temple at Tiruvenkadu (Akaramutalvan n.d., 8). The image of the dancer Paravai Nachayar, a consort of one of the Saiva saints Sundarar, is also consecrated and worshipped in many temples.

\section{AUTHORITATIVE DEPICTIONS OF THE FEMININE: FACT OR FICTION?}

One of the contentious ideas that have been construed from Gimbutas' writing was that Neolithic Old Europe with its many representations of the feminine, and its lack of weapons of warefare represented a peaceful 'matriarchial' or femininefriendly culture which was then overrun by more patriarchial Indo-European speakers. Detractors have also argued against attaching too much symbolism to depictions or figurines with respect to fertility. The idea that the worship of the mother goddess implies a higher status and respect for women is one that may be met with a measure of scepticism. There are, nevertheless, some interesting observations that can be made from the subcontinent. In the Harappan context too, the lack of weapons of war seems a 
striking feature. Even though, the wide acceptance of 'Hinduistic' Goddess worship in India does not equate to a high status for women in a still largely feudalistic society compared to many parts of the world, nevertheless, it is in southern India where Goddess worship is most prevalent (along with some traditions of matrilineage) that the status of women is better than elsewhere in the subcontinent and various places, as seen in the developmental indices, followed by northeastern India where traditions of matrilineage also existed and eastern India where Goddess worship has also been significant.

Although the highly patriarchal Brahmanical laws of the Sanskrit treatise of the Manu Smriti codified around $200 \mathrm{CE}$ come most readily to mind in respect to the status of Hindu women (eg. Dewaraja 1993), several traditional practices amongst indigenous Indian 'tribes' and certain castes particularly in South India and other peripheral regions such as northeastern India have in fact been at variance with such mainstream patriarchal customs. In parts of south western India, along the coast of Karnataka and Kerala, the prevalence of matrilineal institutions and inheritance through women has been recorded among even lay women in the early medieval period; as noted by Ghosh $(1992,263,277)$ who studied the Geniza documents of Jewish merchants in Cairo from c. $1100 \mathrm{AD}$. Matrilineage is also recorded in the Satavahana period: a figure at the Amaravati stupa is said to have been presented by a lady of the name Gautami while her son, the well-known Satavahana king, took his mother's name as Gautamiputra (son of Gautami) Satakarni (Aravamutham 1931, 18). Matrilineage has also been practiced in the northeastern region of Manipur.

The various martial depictions of Kali and Durga in sculpture and bronze may not have been totally dissociated from historical contexts. The legend of the martial Tamil goddess Meenakshi may hark back to a Pandyan warrior princess who is mentioned as having ruled in the Madurai region in a Greek record of 320 вс by Megasthenes, the Greek ambassador to the court of King Chandragupta Maurya, and a mention of Pandae, a land ruled by women (Caldwell 1989, 16; Srinivasan 1996). Hero stones were often erected in honour of women fighters in medieval southern India.

Kuppuram (1986, 125-129) points out that a study of inscriptions suggest that women in Chola society in Tamil Nadu and Karnataka had considerable status. They enjoyed property rights, even after widowhood, and royal women were accorded independent powers by the kings. They played a dominant role in state and in patronage and in the issuing of grants (Venkataraman 1976; Srinivasan 1996). Kaimal (1996) points out that apparently the donation of temples and art lay almost exclusively within the female sphere of authority in $10^{\text {th }}$ century south India (as also observed under the Satavahanas and Iksvakus). She opined that this derived from kinship patterns and endogamous cross-cousin marriages that could have enhanced women's positions in their husband's households through their natal relatives.

Nilakanta Sastri $(1958,60)$ postulated that matrilocal customs such as the practice of inheritance through women recorded in parts of southern Indian (such as amongst the Nair community in Kerala) may have a long history that could be an indicator of ancient cultural affinities between Dravidian, Indus Valley and Mesopotamian Elamite societies. Kenoyer (1998) mentions evidence for matri-local burials at Indus Valley sites suggesting that women enjoyed powerful positions in Harappan society. Thus, some of these case studies from the Indian subcontinent serve, if anything, to underscore the deeply incisive vision and depth of Gimbutas' scholarship.

\section{ACKNOWLEDGEMENTS}

I am grateful to support given by Dr Mark Kenoyer for the photograph of the Harappan plano convex tablet, by Dr Richard Blurton for allowing me 
to photograph the Nilgiri material in British Museum, by Dr Ravi Korisettar for a visit Sanganakallu, by Dr John Marr for the photograph of the Mohenjodaro dancing girl, by Swaminathan Natarajan for the photograph of the Nishumbhasudani from Government Museum, Chennai, by Dr Uday Kumar for the sketches, by Mr Digvijay Mallah for fieldwork in the Nilgiris and by Mr Baalaji. I am grateful to Dr Agnè Čivilytė for suggesting the interesting topic for exploration.

\section{REFERENCES}

Akaramutalvan, T., n.d. Tiruvenkattu ttalavaralaru. (History of the site of Tiruvenkadu). Tiruvenkadu: Svetaranyasvami Devasthanam.

Aravamurthan, T. G., 1931. Portrait Sculpture of South India. London: India Society.

Becker, V., 2007. Early and middle Neolithic figurines-The migration of religious belief. Documenta Praehistorica XXXIV, 119-127.

Caldwell, B., 1989. The History of Tinnevelly. Asian Educational Services (Reprint).

Caubet, A., 2019. Idols: The Power of Images. Skira Editore.

Campbell, S., 1992. The Halaf Period in Iraq: Old Sites and New. Biblical Archaeologist, 55, 182-187.

Dewaraja, L., 1993. Buddhist women in Sri Lanka. Asian Art, Art and Architecture of Sri Lanka, 4, (3), 72-87.

Gerasimov, M., 1964. The Paleolithic site of Malta: excavations of 1956-1958. In: Michael, E.N., (ed.). The Archaeology and Geomorphology of Northern Asia. University of Toronto: Arctic Institute of North America, 5, 3-32.

Ghosh, A., 1992. In an Antique Land. New Delhi: Ravi Dayal.

Gimbutas, M., 1974. The Gods and Goddesses of Old Europe, 7000-3500 BC. Myths, Legends and Cult Images. London: Thames and Hudson.
Gimbutas, M., 1991. The Civilization of the Goddess: The World of Old Europe. San Fransisco: Harper.

Gimbutas, M., 2001. The Living Goddesses. Berkeley, University of California Press.

Gimbutas, M., 2006. Language of the Goddess: Unearthing the Hidden Symbols of Western Civilization. London: Thames and Hudson.

Hocking, P., 1975. Paikara: An Iron Age Burial in South India. Asian Perspectives, 18, 1, 26-50.

Isaac, A., 2019. Major discovery in Tamil Nadu: A possible link to Indus Valley Civilsation. Newsminute, available from: https://www.thenewsminute. com/article/major-discovery-tamil-nadu-s-keezhadipossible-link-indus-valley-civilisation-109165.

Jarrige, C., 1988. Les figurines humaines au Baluchistan. In: Jarrige, J.F., (ed.). Les Cites Oubliees de L'Indus. Musee National des Arts Asiatiques Guimet, 65-70.

Jarrige, J., 1993. The early architectural traditions of greater Indus as seen from Mehrgarh, Baluchistan. In: Spodek, H., (ed.). Urban Form and Meaning in South Asia: The Shaping of Cities from Prehistoric to Precolonial Times. Washington DC: National Gallery of Art.

Joshi, J.P., Parpola, A., 1987. Corpus of Indus seals and inscriptions, 1, Collections in India (= Annales Academiae Scientarum Fennicae, SarjaSer. B, Nide- Tom. 239). Helsinki: Suomalainen Tiedeakatemia.

Kaimal, P., 1996. Early Cola kings and "Early Cola temples": Art and the evolution of kingship. Artibus Asiae, LVI, 1/2, 33-68.

Kenoyer, M., 1998. Ancient Cities of the Indus Valley Civilization. Karachi: Oxford University Press and American Institute of Pakistan Studies.

Kinsley, D., 1987. Hindu Goddesses: Visions of the Divine Feminine in the Hindu Religious Tradition. New Delhi: Motilal Banarsidass. 
Korisettar, R., Prasanna, P., 2014. History of Ancient India II: Protohistoric Foundations. Aryan Books International.

Krishna, N., 2012. Tree worship in the Indus Civilisation. In: Manatunga, A., (ed.). Asian Art and Culture: A Research Volume in Honour of Ananda Coomaraswamy. Kelaniya: Centre for Asian Studies, 139-148.

Krishnamurthi, S. R., (ed.). A Study on the Cultural Developments in the Chola Period. Madras: Annamalai University.

Kuppuram, G., 1986. Imperial Cholas of Karnataka. Delhi: Sundeep Prakashan.

Malagi, Sh., 2016. Gondi script found in Hampi. Deccan Chronicle, available from: https://www. deccanchronicle.com/nation/current-affairs/130216/ gondi-script-found-in-hampi.html.

Nagappa, A., 2000. Gobekli Tepe, Anatolia, Turkey-the Womb of the Mother Goddess. In: Meaden, T., Bender, H., (eds). Anthropomorphic Images in Rock Art Paintings and Rock Carvings. Oxford: Archaeopress, 101-120.

Nagaswamy, R., 1988. South Indian bronzes. In: Khandalavala, K., (ed.). The Great Tradition - Indian Bronze Masterpieces. New Delhi: Festival of India, 142-179.

Naik, I., 1966, The Culture of the Nilgiri hills with its catalogue collection at British Museum, Unpublished PhD dissertation, University of London.

Nilakanta Sastri, K. A., 1958. A History of South India-from prehistoric times to the fall of Vijayanagar. London: Oxford University Press.

Pandey, A., 2020. Shakti: 51 Sacred Pithas of the Goddess. Rupa Publications.

Parpola, A., 1988. Religion reflected in the iconic signs of the Indus script: penetrating into long forgotten pictographic messages. Visible Religion, 6,114-135.

Parpola, A., 1994. Deciphering the Indus Script. Cambridge University Press.
Possehl, G., 2002. The Indus Civilisation: A Contemporary Perspective. Oxford: Altamira Press.

Priyanka, B., 2003. New iconographic evidence for the religious nature of Indus seals and inscriptions. East and West, 53 , 1/4, 31-66.

Rao, S.R., 1973. Lothal and the Indus Civilization. Bombay: Asia Publishing House.

Schmid, Ch., 2011. Rite and Representation: Recent discoveries of Pallava Goddesses of the Tamil Land. Visuality of Indian Rituals, 63 (2), 84-90.

Selvam, N., 2021. Rock art with links to Indus Valley found in Tamil Nadu. The Times of India, available from: https://timesofindia.indiatimes.com/ city/coimbatore/rock-art-with-link-to-indus-valleyfound/articleshow/82235800.cms.

Sircar, J., 2016. In search of Durga. Sutra Journal, available from: http://www.sutrajournal.com/ in-search-of-durga-by-jawhar-sircar.

Spretnak, Ch., 2011. Anatomy of a Backlash: Concerning the Work of Marija Gimbutas. Journal of Archaeomythology, 7, 1-27.

Srinivasan, S., 1996. The enigma of the dancing 'pancha-loha' (five-metalled) icons: archaeometallurgical and art historical investigations of south Indian bronzes. Unpublished $\mathrm{PhD}$. Thesis. London: Institute of Archaeology, University of London.

Srinivasan, S., 1999. Lead isotope and trace element analysis in the study of over a hundred South Indian metal icons. Archaeometry, 41 (1), 91-116.

Srinivasan, S., 2004. Siva as cosmic dancer: On Pallava origins for the Nataraja bronze. World Archaeology, 36 (3), 432-450.

Srinivasan, S., 2016. Tamil Chola bronzes and Swamimalai Legacy: Metal Sources and Archaeotechnology. Journal of Metals, 68 (8), $2207-$ 2221. DOI: 10.1007/s11837-016-1959-1.

Thoury, M., Mille, B., Severin-Fabiani, R., Refregiers, M., Jarrige, J-F., Bertrand, L., 2016. High spatial dynamics-photoluminescence imaging reveals the metallurgy of the earliest lost-wax cast object. Nature Communications, 13356. 
Tiwari, J.N., 1971. Studies in Goddess Cults in Northern India, with Reference to the First Seven centuries CE. Unpublished PhD. Thesis, Australian National University.

Vasudevan, S., 1990. Deity as a social prism: A study of Korravai (Durga). Proceedings of the Indian History Congress, 51, 122-126.

Venkataraman, B., 1976. Temple Art under the Chola Queens. Faridabad: Thomson Press.

Walker, B., 1983. The Woman's Encyclopedia of Myths and Secrets. Harper One.
Walker, B., 2000. Restoring the Goddess. Prometheus Books.

Wheeler, M., 1953. The Indus Civilization. Cambridge University Press.

Younger, P., 1995. The Home of Dancing Sivan: The traditions of the Hindu temple in Citamparam. Oxford University Press.

Zarrilli, P., 1998. When the body becomes all eyes: Paradigms, discourses and practices of power in Kalarippayattu, a south Indian martial art. Delhi: Oxford University Press.

\title{
GODDESS WORSHIP AND THE DANCING FORM: EXPLORING RITUAL IN INDIAN PREHISTORY AND SOUTH INDIAN ANTIQUITY
}

\author{
Sharada Srinivasan
}

\section{Summary}

The work of the Lithuanian archaeologist Marija Gimbutas, which innovatively explored feminine representations in the archaeological record going back to Neolithic Europe particularly in the context of ritual and worship, provides interesting pathways and frameworks for broader global explorations. The Indian subcontinent provides particularly fertile material, with some of the longest surviving traditions of figural representations of feminine forms and goddess worship. At the same time, it also provides an interesting field to explore analogies from the approaches of researchers on prehistoric material culture such as Gimbutas due to its largely enigmatic and fragmented pre-history and protohistory with the script of the Indus Valley (IVC) or Harappan civilization being as yet undeciphered.

The insights of Gimbutas and other scholars into symbolic representations of the feminine, exploring connotations of fertility, from Neolithic Europe and the Near East and Anatolia, including sites such as
Göbekli Tepe (c 10000 BCE) and Catal Hayuk, are touched upon. The related comparisons of ceramics of female 'goddess' figurines from Neolithic and Pre-Harappan Baluchistan and continuing into the Mature Harappan ( 2500 вСЕ), although these are more ornamented than western counterparts. Despite the long hiatus in the post-Harappan period, they bear comparisons with terracotta and other finds of 'Yakshi' figurines associated with tree worship and fertility which again surface the early historic India by the common era. The paper focuses on lingering strands of continuity from the prehistory and protohistory of the Northwestern subcontinent, into southern India, where Goddess worship is most deeply and widely entrenched. The finds of related figurines such as the small bronze 'mother goddess' from Iron Age Adichanallur (c $800 \mathrm{BCE}$ ) and terracottas from the Nilgiris from Tamil Nadu, take on added significance in the light of recent excavations from Keeladi, near Madurai 
in Tamil Nadu, with urbanised features dating back to the 6th century вСЕ and finds of potsherds with signs resembling IVC ones. These lend strength to theories of movements of proto-Dravidian/Dravidian speakers from the northwest and Indus region (where the Dravidian language of Brahui still survives in Baluchistan) into southern India.

South Indian Neolithic material culture from the site of Sanganakallu in Karnataka, c 3000 BCE, with rock art depictions of humped cattle associated with Harappan seals, provides some interesting insights. The dolerite dykes have numerous cupules that give resonant tones, flanked by rock art of lines of dancers with linked hands (as still practiced by tribal Indian communities), which suggests that they could have been used as spaces for ritual dance and music. A large rock pictograph of a female figure is also significant to discussions on Neolithic goddess worship. Intriguing links to Harappan motifs and signs are found such as the endless knot, still practiced as Kolam in southern India, and in rock art from Melumalai (mel: upper, malai: hill in Tamil) in Tamil Nadu. Meluhha, the place name for the Harappan region in Sumerian, is not inconsistent with Tamil place names like Meluru and Melumalai. In central, eastern and southeastern India, speakers the proto-Dravidian Gondi language, traditionally performed dances with bison horns, recalling to horned deities depicted in Harappan seals; and attention is drawn in this paper to some of their intriguing claims concerning south Indian rock art and IVC signs.

Following in this vein, the worship of the martial Goddess Kottravai, mentioned in early historic Sangam Tamil poetry and well depicted in $5^{\text {th }}-7^{\text {th }}$ steles and Pallava sculpture is explored. Scholars have pointed to related martial Indian goddesses of Durga riding the lion and impaling the buffalo demon, or Kali (for whom an analogy is not found in Vedic Sanskritic literature but who became popular in later Puranic lore) and recalling to seal motifs from Harappa. While pointing to the connections with
Sumerian and Anatolian epic or artistic depictions, this paper also points to more distinctive connections between Kottravai and the wider prehistory of West Asia and the Mediterranean and north-western India related to myths of slaying the buffalo demon. These include the similarities with the name of a Baluch goddess Kottavi, and Gondi hunting goddess Kotamma, while Kottravai is also depicted with a blackbuck in early steles, an animal also found in the Baluch region. The Pallava depictions of the goddess standing on the head of the buffalo are also distinctive and recall to West Asian bucrania such as from Göbekli Tepe. Connections with Indus seal depictions of a figure on a tree beckoning a tiger and the impaling of a water buffalo are made. The balletic $7^{\text {th }}$ century Pallava monolithic frieze of Kottravai on a feline chasing the buffalo-headed male demon Mahishasura is intriguing even the light of depictions of the Sumerian bull-headed half-male Enkidu from distant antiquity. It is also tempting to see distant antecedants or continuities for the bronze 'dancing girl' statuettes from Mohenjodaro in aspects of the medieval south Indian ritual milieu. Women as ritual dancers were prominently attached to south Indian temples until recent times, while Chola bronze processional deities also prominently depicted dancing forms of the martial goddess, some of which were also technically studied by the author.

The relevance of Gimbutas' discussions on faunal and floral anthropomorphic imagery related to fertility in the context of Neolithic Europe, is also explored. These include the interpretation of a V sign held by a female figure in a Harappan seal as a possible fertility sign, inspired by the vulva, and an inverted figure with a sprouting plant as a sign of fertility, akin to the bee-goddess mentioned by Gimbutas. The context of the manufacture of terracotta figurines amongst the indigenous people of the Nilgiris in Tamil Nadu, and the exclusively women potters amongst the Kotas, suggests that pottery in antiquity need not be seen only through 
the lens of the male gaze; and that the makers of early female figurines could have been women themselves. Finally, it is suggested that the contention of Gimbutas that the female figurines of European prehistory, predating the advent of Indo-European speakers, represented earlier patterns of female ritual veneration within 'matriarchial' societies, where women had their prominence, is not entirely unreasonable. This seems to be also reflected by the Indian evidence whereby it is pointed out that it is in the southern Indian regions where Goddess worship has prevailed that the most historical, inscriptional and recent anthropological evidence can be found for the prevalence of matrilineal and matriarchial practices and with a relatively more egalitarian ethos, followed by northeastern and eastern India.

\title{
DEIVĖS GARBINIMAS IR ŠOKIO JUDESIO FORMA: RITUALAI INDIJOS PRIEŠISTORE்JE IR PIETŲ INDIJOS ANTIKOJE
}

\author{
Sharada Srinivasan
}

Santrauka

Lietuvių archeologė Marija Gimbutienè savo darbuose pateikè inovatyvias moters vaizdavimo neolito laikotarpyje archeologinès medžiagos, ypač ritualų ir garbinimo, interpretacijas. Jos darbai įkvėpė sukurti naujas tyrimų sistemas ir prieigas, naudojamas visame pasaulyje. Indijos subkontinente ypač gausu seniausios figūrinio moters vaizdavimo tradicijos ir deivių garbinimo medžiagos. Pastarąją įdomu palyginti su analogiškais priešistorinès materialiosios kultūros tyrimais, atliktais M. Gimbutienès, nes Indijos subkontinentas pasižymi mįslinga ir tik iš dalies aiškia priešistore bei protoistorija. Be to, gerai žinomas Harapos civilizacijos raštas (taip pat vadinamas Indo raštu) iki šiol yra neiššifruotas.

Šiame straipsnyje apžvelgiamos M. Gimbutienès ir kitų mokslininkų įžvalgos apie simbolinị moters vaizdavimą bei vaisingumą. Aptariami neolito laikotarpio Europos, Artimųjų Rytų ir Anatolijos (ir Giobekli Tepès (apie 10000 m. pr. Kr.) bei Čatal Hiujuko) vietovių pavyzdžiai. Palyginimui aprašomos molinès Beludžistano moters (deivès) figūrèlès, datuojamos laikotarpiu tarp neolito ir iki Harapos civilizacijos susikūrimo, besitęsiančiu iki brandžiosios Harapos stadijos (apie 2500 m. pr. Kr.). Tiesa,
Beludžistano figūrèlès puoštos gausiau nei radiniai Vakaruose.

Nepaisant ilgos spragos laikotarpyje po Harapos civilizacijos, vis vien j̨žvelgiama panašumų tarp Beludžistano figūrèlių bei keraminių dirbinių ir Yakshi figūrèlių. Pastarosios grupès dirbiniai siejami su medžių garbinimu ir vaisingumo simbolizmu ankstyvojoje istorineje Indijoje mūsų eros laikotarpyje. Straipsnyje atsekamos priešistorès ir protoistorijos tęstinumo gijos nuo šiaurès vakarų subkontinento iki pat pietinès Indijos, kur deivès kultas viešpatavo ir buvo pasklidęs plačiausiai.

Toliau apžvelgiami reikšmingi Tamilnado radiniai: mažytè bronzinè deivès Motinos figūrèlè (apie 800 m. pr. Kr.), aptikta geležies amžiumi datuojamoje archeologinèje Adichanallur vietovèje, ir Nilgiri Cairns keraminių dirbinių rinkinys. Atsižvelgiant i naujausių kasinejjimų archeologinejje Keeladi vietovejje (šalia Madurajaus, Tamilnado) rezultatus, Adichanallur figūrèlè ir Nilgiri Cairns dirbiniai igyja papildomą reikšmę. Keeladi tyrimai vertinami dèl urbanizaciją liudijančios VI a. pr. Kr. struktūros, taip pat keramikos šukių, ant kurių identifikuota ženklų, primenančių Harapos / Indo rašmenis. Šie 
radiniai sustiprina teoriją, esą protodravidų ar dravidų kalbų vartotojai iš šiaurès vakarų ir Indo regionų (čia dravidų šeimos brahujų kalba iki šiol vartojama Beludžistane) migravo ì pietinę Indiją.

Remiantis Sanganakallu archeologinès vietovès (3000 m. pr. Kr.) radiniais Karnatakoje buvo pateikta ịdomių įžvalgų, susijusių su materialiąja pietų Indijos neolito laikotarpio kultūra. Čia rasti kuprotojo galvijo atvaizdai ant akmens siejami su Harapos atspaudais. Taip pat aptikta dolerito akmenų, ant jų matomi įdubimai, žymès, kuriuos mušant išgaunami rezonuojantys tonai. Vieno dolerito akmens piešinys - eilè rankomis susikibusių šokèjų (taip iki šių dienų šoka Indijos genčių bendruomenès). Šie radiniai leidžia kelti prielaidą, jog ši vieta galèjo būti naudojama kaip erdvè ritualiniams šokiams ir muzikai.

Deivès garbinimo neolito laikotarpyje diskusijai svarbus radinys - didelè moters piktograma. Glaudų ryši su Harapos / Indo motyvais ir simboliais turi „nesibaigiantis“ Kolam tipo mazgas (iki šiol naudojamas pietinejje Indijoje) bei piešiniai ant akmens Melumalai (mel tamilų kalba reiškia viršutinè, malai - kalva) kaimelyje Tamilnade. Meluhha-Harapos regiono vietovardis šumerų kalba sutampa su tamilų kalbos vietovardžiais Meluru ir Melumalai.

Centrinèje, rytinèje ir pietryčių Indijoje gondi (protodravidų) kalbos vartotojai pagal tradiciją šokdavo, pasipuošę bizonų ragais. Toks vaizdinys primena raguotas Harapos antspaudų dievybes. Šiuo straipsniu siekiama atkreipti dèmesi ̣ kai kuriuos intriguojančius teiginius, susijusius su piešiniais ant akmens, rastais pietų Indijoje, bei Indo/ Harapos rašto ženklais.

Dievybių garbinimo tema tęsiama aptariant kovų deivès Kottravai vaizdavimo tradiciją. Šios deivès garbinimas užrašytas istorinejje tamilų Sangam literatūroje (poezijoje). Deivè taip pat aiškiai pavaizduota V-VII a. stelose ir palavų skulptūroje. Mokslininkai atkreipia dèmesị i susijusią indų dievybę Durgą, arba Kali - kovos deivę - kuri, jodama ant liūto, pasmeigè buivolo pavidalo demoną (šios deivès analogų nerandama vedų sanskrito literatūroje, tačiau matyti išaugęs jos populiarumas vèlesniuose Puranos pasakojimuose). Minèti vaizdiniai taip pat turi panašumų su Harapos antspaudų motyvais. Šiame straipsnyje išryškejja šumerų ir Anatolijos meninių ar mitus iliustruojančių vaizdinių sąsajos, taip pat platesni deivès Kottravai garbinimo tradicijos ir vakarų Azijoje, Viduržemio jūros regione bei šiaurès vakarų Indijoje gyvavusio mito apie buivolo pavidalo demono nugalejjimą ryšiai. Šios sąsajos atsirado dèl deivių vardų panašumo, pavyzdžiui: beludžių deivė vardu Kottavi, o gondi medžioklès deive - Kotamma. Be to, ankstyvosiose stelose deivė Kottravai vaizduojama su elniaože gazele, paplitusia Beludžistano regione. Pulavai taip pat vaizdavo deivę, stovinčią buivolui ant galvos. Susiję vaizdiniai aptikti vakarų Azijoje, archeologinejje Giobekli Tepès vietoveje. Tolimesnès sąsajos - Harapos antspaudų vaizdiniai: žmogaus figūra, sẻdinti ant medžio ir viliojanti tigrą, figūra, nudurianti vandens buivolą. Intriguojančiu laikomas VII a. Palavos frizas, kuriame deivė Kottravai joja ant kačių šeimos gyvūno ir vejasi Mahišą - demoną su buivolo galva - o jo analogija laikomas šumerų Enkidu (žmogus jaučio galva) iš tolimosios Antikos laikų.

Toliau straipsnyje aprašoma bronzinė šokančios mergaitès figūrèlè, rasta Mohendžo Dare, kurią autorè ịvardija kaip galimą pirmtakę ir izžvelgia tęstinumą kai kuriuose viduramžiais pietų Indijoje praktikuotose ritualuose. Iki pat šių dienų moterys, šokančios ritualinius šokius, siejamos su pietų Indijos šventyklomis. Be to, bronzinès Čolų procesinės dievybės dažniausiai pavaizduotos kaip šokanti kovos deivè. Autorè pateikia techninę šių figūrèlių apžvalgą.

Straipsnyje autore pateikia svarstymus, susijusius su M. Gimbutienès diskusijomis apie antropomorfinius gyvūnų ir augalų vaizdinius ir vaisingumą neolito laikotarpio Europoje. Aptariama ir interpretacija, kurioje teigiama, jog viename Harapos antspaude pavaizduota moters figūra, su V ženklu, galbūt 
vulvos vaizdiniu, galejjusi simbolizuoti vaisingumą. Taip pat minimas apverstos figūros su dygstančiu augalu (irgi vaisingumo ženklas) piešinys; ji primena M. Gimbutienès minètą bičių deivę.

Vietinių Nilgirio žmonių Tamilnade pagamintos terakotos figūrèles, taip pat vien tik kotų genties moterų gaminta keramika rodo, kad Antikos laikų keramika neturètų būti priskiriama vien vyrų aplinkai. Gali būti, jog ankstyvųjų moters figūrèlių kūrèjos galejjo būti pačios moterys.

Pabaigoje autorè pripažǐsta, jog M. Gimbutienès teiginys, kad priešistorinès Europos moterų figūrèlès (sukurtos dar prieš prieš indoeuropiečių kalbos vartotojų atsiradimą) atskleidè ankstesnius ritualinius moterų garbinimo modelius matriarchinèse visuomenėse, kai moterys užèmė svarbiausias pozicijas, yra pakankamai pagrịstas. Ši teiginị pagrindžia ir duomenys iš pietinių Indijos regionų, kur vyravo deivès garbinimas. Čia rasta daugiausia istorinių, užrašytų ir naujausių antropologinių duomenų apie matrilininès ir matriarchinès organizacijos paplitimą ir daugiau egalitarinę santvarką. Panaši organizacija aptikta šiaurès rytų ir rytų Indijoje.

Indijos subkontinentas yra vienas iš pasaulio regionų, kuriame deivių garbinimas išliko ilgiausiai. Kertinių Marijos Gimbutienès darbų apie neolito ir bronzos amžių gyvenvietes pietryčių Europoje reikšmè materialinei Indijos subkontinento kultūrai iki šiol nebuvo pakankamai dèmesingai tyrinèta. Ypač reikšmingos moters figūrèlių kaip galimos deivès garbinimo išraiškos studijos. Be to, kai kurie išlikę deivès garbinimo ritualai ir ikonografija galètų padèti atskleisti iki šiol neišaiškintus neolito laikotarpio archeologinių radinių aspektus, ir ne tik subkontinento, bet ir Antikos kontekste. Šiame straipsnyje taip pat tyrinejjama šokio judesio forma ritualuose, ypač susijusiuose su deivès garbinimu. Šokis, kaip iš senovès atkeliavęs ypatumas, Indijoje matomas ryškiau nei daugelyje pasaulio vietų.

Vertè Agnè Čivilytè

Gauta: 20211028 Priimta: 20211119 